\title{
The Role of the Corporation in Fostering Sustainable Peace
}

\author{
By: Timothy L. Fort and Cindy A. Schipani
}

William Davidson Working Paper Number 422

November 2001 
THE ROLE OF THE CORPORATION IN FOSTERING SUSTAINABLE PEACE*

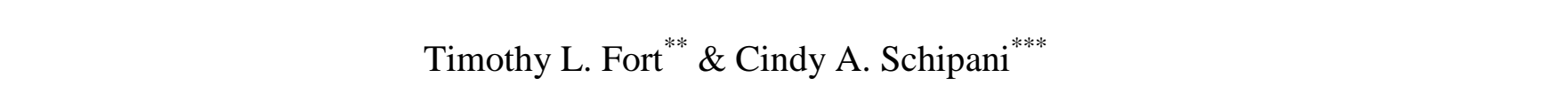

DRAFT $11 / 21 / 01$

\footnotetext{
* Copyright 2001. Timothy L. Fort and Cindy A. Schipani. All rights reserved. The authors would like to gratefully acknowledge the support of the William Davidson Institute at the University of Michigan.

* Associate Professor of Business Ethics and Business Law, University of Michigan; Area Director, Corporate Governance and Corporate Social Responsibility, William Davidson Institute.

${ }_{* * * *}$ Professor of Business Law, University of Michigan; Area Director, Corporate Governance and Corporate Social Responsibility, William Davidson Institute.
} 
A front page May 20, 2001 New York Times news stories reported that Hindus in scattered areas of the world are protesting McDonald's decision to cook its French fries in beef fat, although in 1990, it had announced that it would cook its fries only in vegetable oil. 'DAs a result, "the news ricocheted to India, where restaurant windows were smashed, statues of Ronald McDonald were smeared with cow dung, and Hindu nationalist politicians called for the chain to be evicted from the country. ${ }^{2}$ The controversy is not the first McDonald's has faced. Even a well-toned Prince Philip of England stated that "You people [McDonald's] are destroying the rainforests of the world by grazing your cheap cattle."’3 And as McDonald's CEO, Jack Greenberg, acknowledged and defended McDonald's record, the company is challenged on issues from undermining local farmers, threatening local culture, using genetically modified organisms in its food, relying on hormonally treated beef, opposing local unionization, distributing unsafe toys to children, and employing child labor. ${ }^{4} \rrbracket$ Such a seemingly ubiquitous problem-causing image may be why another journal not known for its left-leaning views, The Economist, jokingly began a recent story with "Scientists at the McDonald's Centre for Obesity Research suggest that eating a hamburger a day actually reduces cholesterol levels." $[$ This in a story that suggests that the scientific community is beholden to the corporations funding its research..$^{6}$

On the other hand, not only may McDonald's cite the employment it brings to local areas, but its influence not only on economic affairs, but perhaps even peace, has been trumpeted as well. In a more serious vein, at least somewhat so, The Economist uses the price of a McDonald's hamburger in different countries as a way to assess distortions in the exchange rate of

\footnotetext{
${ }^{1}$ Laurie Goodstein, Hindus and Vegetarians in Court As McDonald's Puts Beef in Fries, NY TIMES, May 20, 2001, at $\mathrm{A} 1$.

${ }^{2}$ Id.

${ }^{3}$ McAtlas Shrugged, FoREIGN POL’Y, May-June 2001 at 26.

${ }^{4} I d$. at 26-32.

${ }_{6}^{5}$ Going for Gold, THE ECONOMIST, May 19, 2001, at 15.

${ }^{6} \mathrm{Id}$.
} 


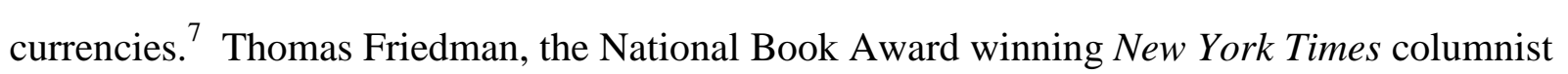
has advanced a theory called "The Golden Arches Theory of Conflict Prevention," claiming that "no two countries that both had McDonald's had fought a war against each other since each got its McDonald's." NATO and Yugoslavia, where all countries had McDonald's. Indeed, he contended that the turning point of that conflict occurred when NATO bombed the power grids and therefore eliminated the benefits of a networked global economy for the people, including the convenience of consuming a Big Mac. ${ }^{-}$Thus, although there is now, according to Friedman, an exception to the Golden Arches Theory, the power of globalization works to mitigate the extent of conflict. 10

These examples illustrate much of the complexity involved in assessing the ways multinational corporations may or may not foster beneficial relationship among the people they encounter. From these limited comments regarding McDonald's, one could hypothesize several potential theories.

1. Multinational corporations cause unrest, protest, and bitterness;

2. Multinational corporations are convenient scapegoats to blame because of their power and their facelessness;

3. The influence of multinational corporations is so fundamental that they undermine even seemingly objective analysis of contemporary issues (such as scientific analysis);

\footnotetext{
${ }^{7}$ McAtlas Shrugged, supra note 3, at 31.

${ }^{8}$ Thomas L. FriedMAN, THE LEXUS AND THE OlIVE TREe 248 (2000).

${ }^{9} I d$. at $252-53$.

${ }^{10} I d$. at 253.
} 
4. The influence of multinational corporations is so fundamental that they have the potential to build a Pax E-Commercia ${ }^{112}$ that philosophers such as Kant $\frac{12}{\text { only hoped }}$ to realize.

In short, the relationship between corporate action and an ideal such as sustainable peace seems to be ambiguous. Within ambiguity, however, there may lay patterns of relationships that can be elucidated. To date, very little attention has been devoted to this topic. ${ }^{13}$ In this article, we hope to join in this initial dialogue and offer the following observations.

First, there is a plausible, conceptual relationship among corporate governance, business ethics, and sustainable peace. Accordingly, Section One is concerned with developing this connection in terms of recognizing the protests against as well as the benefits of globalization, the reciprocal benefits between stable geopolitical entities and economic activity, and specific historical events that collectively add to the ambiguity, but which may also contain foreshadow of patterns to be illuminated.

Section Two looks more deeply at those patterns. In this section, we argue that the contribution multinational corporations make to sustainable peace is more likely in mitigating internal wars rather than wars between sovereign nations. There are exceptions. Sometimes, economic exchange may reduce the likelihood of warfare between countries. The April downing of the U.S. spyplane in China may well have had a different outcome if the economic exchanges between the two countries were not already so great $t^{14}$ and their potential for increase so large. 5 Nevertheless, we believe that the more promising area for corporate contributions to peace may

\footnotetext{
${ }^{11}$ We borrow this term, with its Internet twist from Timothy L. Fort \& James J. Noone, Gifts, Bribes and Exchanges in Pre-Market Economies: Lessons for Pax-E Commercia, 33 CORNELL INT'L L. J. 515, 515 (2000).

${ }^{12}$ See Immanuel Kant, Perpetual Peace: A Philosophical Sketch, in Political Writings (HANS REISS, ED. 7 H.B. NISBET, TRANS. 2D ED. 1991).

${ }_{13}^{13}$ See other articles in this symposium. These authors are among the first to systematically reflect on these issues.

${ }^{14}$ Paula Lyon Andrews, Slow Boat to China, MARKETING NEWS, Sept. 10, 2001, at 1.

15 Trish Saywell, Powering Asia's Growth, FAR E. ECON. REV., Aug. 2, 2001, at 40.
} 
lay in the way corporations do their work in countries through economic progress in general and through mitigation of existing rivalries in the workplaces. If this contribution is a valuable one, then the way in which corporations are governed will make a difference to the ethical values that are promoted within the workplace. This governance question lays bare the assumptions underlying the reasons for which corporations are established.

Finally, we will conclude with our observation that enough evidence exists to move beyond being content with a plausible relationship among governance, ethics, and peace and suggest that future work may uncover increasingly precise corporate models that contribute to the reduction of bloodshed. If this argument is true, of course, the stakes for corporations to practice ethically responsible governance practices increase dramatically, as does the pressure on governments to create legislative frameworks to encourage responsible governance practices. 


\section{THE PLAUSIBILITY OF CONNECTING GOVERNANCE, ETHICS, AND PEACE: THE IMPORTANCE OF TRANSPARENCY}

In this section, we demonstrate that there is a plausible correlative and conceptual connection among governance, ethics, and peace. For purposes of this paper, we wish to sketch this correlative connection by providing an initial empirical link between corruption and peace and then, in interpreting this data, we provide a conceptual rationale for the connection and further link this connection to corporate governance. Finally, we further identify the most telling connections. An underlying theme is the need for transparency of governmental and corporate processes in order to battle corruption.

\section{A. An Initial Empirical Connection}

Transparency International ("TI") is a non-governmental organization, which attempts to document the level of corruption that exists within countries today ${ }^{16}$ As its chairman, Peter Eigen, states "the scale of bribe-paying in international corporations in the developing countries of the world is massive ...[and] ... the results include growing poverty in poor countries, persistent undermining of the institutions of democracy, and mounting distortions in fair international commerce. ${ }^{, 17}$ In attempting to determine perceptions of the level of corruption in countries TI conducted 779 interviews with representatives of companies doing business in emerging markets. ${ }^{18}$ In conjunction with this index devoted specifically to bribe-taking, TI also

\footnotetext{
${ }^{16}$ See generally, Transparency International, at http://www.transparency.de (last visited Nov. 20, 2001).

${ }^{17}$ Peter Eigen, The Transparency International Bribe Payers Survey, at www.transparency.de/documents/cpi/1999/bps.html (last visited Nov. 20, 2001).

${ }^{18} I d$.
} 
utilizes other indices to create a "Corruption Perceptions Index." $" 10$ The rankings of these ninety countries provides an indication of levels of corruption that exist today and is reproduced below:

The 2000 Corruption Perceptions Index 20

\begin{tabular}{|c|c|c|c|c|c|}
\hline $\begin{array}{l}\text { Country } \\
\text { Rank }\end{array}$ & Country & \begin{tabular}{|l|}
2000 \\
CPI \\
Score
\end{tabular} & $\begin{array}{l}\text { Surveys } \\
\text { Used }\end{array}$ & $\begin{array}{l}\text { Standard } \\
\text { Deviation }\end{array}$ & High-Low Range \\
\hline 1 & Finland & 10.0 & 8 & 0.6 & $9.0-10.4$ \\
\hline 2 & Denmark & 9.8 & 9 & 0.8 & $8.6-10.6$ \\
\hline \multirow{2}{*}{3} & New Zealand & 9.4 & 8 & 0.8 & $8.1-10.2$ \\
\hline & Sweden & 9.4 & 9 & 0.7 & $8.1-9.9$ \\
\hline 5 & Canada & 9.2 & 9 & 0.7 & $8.1-9.9$ \\
\hline \multirow{3}{*}{6} & Iceland & 9.1 & 7 & 1.1 & $7.3-9.9$ \\
\hline & Norway & 9.1 & 8 & 0.7 & $7.6-9.5$ \\
\hline & Singapore & 9.1 & 11 & 1.0 & $6.2-9.7$ \\
\hline 9 & Netherlands & 8.9 & 9 & 0.6 & $8.1-9.9$ \\
\hline 10 & United Kingdom & 8.7 & 9 & 0.6 & $7.3-9.7$ \\
\hline \multirow{2}{*}{11} & Luxembourg & 8.6 & 7 & 0.7 & $7.4-9.3$ \\
\hline & Switzerland & 8.6 & 8 & 0.3 & $8.1-9.1$ \\
\hline 13 & Australia & 8.3 & 10 & 1.0 & $6.7-9.3$ \\
\hline 14 & USA & 7.8 & 10 & 0.8 & $6.2-9.2$ \\
\hline \multirow{2}{*}{15} & Austria & 7.7 & 8 & 0.7 & $6.2-8.5$ \\
\hline & Hong Kong & 7.7 & 11 & 1.2 & $4.3-8.6$ \\
\hline 17 & Germany & 7.6 & 8 & 0.8 & $6.2-8.4$ \\
\hline 18 & Chile & 7.4 & 8 & 0.9 & $5.7-8.4$ \\
\hline 19 & Ireland & 7.2 & 8 & 1.9 & $2.5-8.5$ \\
\hline 20 & Spain & 7.0 & 8 & 0.7 & $5.9-8.0$ \\
\hline 21 & France & 6.7 & 9 & 1.0 & $4.3-7.7$ \\
\hline 22 & Israel & 6.6 & 8 & 1.3 & $4.3-7.9$ \\
\hline \multirow{2}{*}{23} & Japan & 6.4 & 11 & 1.3 & $4.3-7.8$ \\
\hline & Portugal & 6.4 & 9 & 0.9 & $5.3-8.1$ \\
\hline 25 & Belgium & 6.1 & 9 & 1.3 & $4.3-8.8$ \\
\hline 26 & Botswana & 6.0 & 4 & 1.6 & $4.3-8.2$ \\
\hline 27 & Estonia & 5.7 & 4 & 1.6 & $4.4-8.1$ \\
\hline \multirow{2}{*}{28} & Slovenia & 5.5 & 6 & 1.1 & $4.1-7.3$ \\
\hline & Taiwan & 5.5 & 11 & 1.4 & $2.5-7.2$ \\
\hline
\end{tabular}

${ }^{19}$ Id. TI notes that there are countries that would likely rank even lower than those indicated in its 2000 Corruption Perceptions Index but insufficient polling data in many countries makes it difficult to assess.

${ }^{20}$ TI, The 2000 Corruption Perceptions Index, at <http://www.transparency.de/documents//cpi/2000/cpi2000.html $>$. 
William Davidson Institute Working Paper 422

\begin{tabular}{|c|c|c|c|c|c|}
\hline \multirow{2}{*}{30} & Costa Rica & 5.4 & 4 & 1.9 & $3.8-8.1$ \\
\hline & Namibia & 5.4 & 4 & 0.8 & $4.3-6.1$ \\
\hline \multirow{2}{*}{32} & Hungary & 5.2 & 10 & 1.2 & $3.9-8.1$ \\
\hline & Tunisia & 5.2 & 4 & 1.5 & $3.8-7.1$ \\
\hline 34 & South Africa & 5.0 & 10 & 0.9 & $3.8-6.6$ \\
\hline 35 & Greece & 4.9 & 8 & 1.7 & $3.7-8.1$ \\
\hline 36 & Malaysia & 4.8 & 11 & 0.6 & $3.8-5.9$ \\
\hline \multirow{2}{*}{37} & Mauritius & 4.7 & 5 & 0.8 & $3.9-5.6$ \\
\hline & Morocco & 4.7 & 4 & 0.7 & $4.2-5.6$ \\
\hline \multirow{2}{*}{39} & Italy & 4.6 & 8 & 0.6 & $4.0-5.6$ \\
\hline & Jordan & 4.6 & 5 & 0.8 & $3.8-5.7$ \\
\hline 41 & Peru & 4.4 & 5 & 0.5 & $3.8-5.0$ \\
\hline 42 & Czech Republic & 4.3 & 10 & 0.9 & $3.3-6.2$ \\
\hline \multirow{5}{*}{43} & Belarus & 4.1 & 3 & 0.8 & $3.4-4.9$ \\
\hline & El Salvador & 4.1 & 4 & 1.7 & $2.1-6.2$ \\
\hline & Lithuania & 4.1 & 4 & 0.3 & $3.8-4.4$ \\
\hline & Malawi & 4.1 & 4 & 0.4 & $3.8-4.8$ \\
\hline & Poland & 4.1 & 11 & 0.8 & $2.8-5.6$ \\
\hline 48 & South Korea & 4.0 & 11 & 0.6 & $3.4-5.6$ \\
\hline 49 & Brazil & 3.9 & 8 & 0.3 & $3.6-4.5$ \\
\hline 50 & Turkey & 3.8 & 8 & 0.8 & $2.1-4.5$ \\
\hline 51 & Croatia & 3.7 & 4 & 0.4 & $3.4-4.3$ \\
\hline \multirow{5}{*}{52} & Argentina & 3.5 & 8 & 0.6 & $3.0-4.5$ \\
\hline & Bulgaria & 3.5 & 6 & 0.4 & $3.3-4.3$ \\
\hline & Ghana & 3.5 & 4 & 0.9 & $2.5-4.7$ \\
\hline & Senegal & 3.5 & 3 & 0.8 & $2.8-4.3$ \\
\hline & Slovak Republic & 3.5 & 7 & 1.2 & $2.2-6.2$ \\
\hline \multirow{2}{*}{57} & Latvia & 3.4 & 3 & 1.3 & $2.1-4.4$ \\
\hline & Zambia & 3.4 & 4 & 1.4 & $2.1-5.1$ \\
\hline 59 & Mexico & 3.3 & 8 & 0.5 & $2.5-4.1$ \\
\hline \multirow{3}{*}{60} & Colombia & 3.2 & 8 & 0.8 & $2.5-4.5$ \\
\hline & Ethiopia & 3.2 & 3 & 0.8 & $2.5-3.9$ \\
\hline & Thailand & 3.2 & 11 & 0.6 & $2.4-4.0$ \\
\hline \multirow{2}{*}{63} & China & 3.1 & 11 & 1.0 & $0.6-4.3$ \\
\hline & Egypt & 3.1 & 7 & 0.7 & $2.3-4.1$ \\
\hline \multirow{3}{*}{65} & Burkina Faso & 3.0 & 3 & 1.0 & $2.5-4.4$ \\
\hline & Kazakhstan & 3.0 & 4 & 1.2 & $2.1-4.3$ \\
\hline & Zimbabwe & 3.0 & 7 & 1.5 & $0.6-4.9$ \\
\hline 68 & Romania & 2.9 & 4 & 1.0 & $2.1-4.3$ \\
\hline 69 & India & 2.8 & 11 & 0.7 & $2.3-4.3$ \\
\hline
\end{tabular}




\begin{tabular}{|l|l|l|l|l|l|}
\cline { 2 - 6 } & Philippines & 2.8 & 11 & 1.0 & $1.7-4.7$ \\
\hline \multirow{3}{*}{71} & Bolivia & 2.7 & 4 & 1.3 & $1.7-4.3$ \\
\cline { 2 - 6 } & Côte-d'Ivoire & 2.7 & 4 & 0.8 & $2.1-3.6$ \\
\cline { 2 - 6 } & Venezuela & 2.7 & 8 & 0.7 & $2.1-4.3$ \\
\hline \multirow{2}{*}{74} & Ecuador & 2.6 & 4 & 1.0 & $2.1-4.3$ \\
\cline { 2 - 6 } & Moldova & 2.6 & 4 & 0.9 & $1.8-3.8$ \\
\hline \multirow{3}{*}{76} & Armenia & 2.5 & 3 & 0.6 & $2.4-3.5$ \\
\cline { 2 - 6 } & Tanzania & 2.5 & 4 & 0.6 & $2.1-3.5$ \\
\cline { 2 - 6 } & Vietnam & 2.5 & 8 & 0.6 & $2.1-3.8$ \\
\hline 79 & Uzbekistan & 2.4 & 3 & 0.9 & $2.1-3.7$ \\
\hline 80 & Uganda & 2.3 & 4 & 0.6 & $2.1-3.5$ \\
\hline 81 & Mozambique & 2.2 & 3 & 0.2 & $2.4-2.7$ \\
\hline \multirow{2}{*}{82} & Kenya & 2.1 & 4 & 0.3 & $2.1-2.7$ \\
\hline & Russia & 2.1 & 10 & 1.1 & $0.6-4.1$ \\
\hline 84 & Cameroon & 2.0 & 4 & 0.6 & $1.6-3.0$ \\
\hline \multirow{2}{*}{85} & Angola & 1.7 & 3 & 0.4 & $1.6-2.5$ \\
\cline { 2 - 6 } & Indonesia & 1.7 & 11 & 0.8 & $0.5-3.2$ \\
\hline \multirow{2}{*}{87} & Azerbaijan & 1.5 & 4 & 0.9 & $0.6-2.5$ \\
\hline & Ukraine & 1.5 & 7 & 0.7 & $0.5-2.5$ \\
\hline 89 & Yugoslavia & 1.3 & 3 & 0.9 & $0.6-2.4$ \\
\hline 90 & Nigeria & 1.2 & 4 & 0.6 & $0.6-2.1$ \\
\hline
\end{tabular}

The Heidelberg Institute for International Conflict Research produces an index related to conflict around the world. 1 This index uses a variety of sources and twenty-eight variables to define the types of conflict involved and the methods used by parties to those conflicts to resolve them.2. "Conflict" is defined as

the clashing of overlapping interests (positional differences) around national values and issues (independence, self-determination, borders and territory, access to or distribution of domestic or international power); the conflict has to be of some duration and magnitude of at least two parties (states, groups of states, organizations or organized groups) that are determined to pursue their interests and win their case. At least one party is the organized state. Possible instruments used in the course of a conflict are negotiations, authoritative decisions, threat, pressure, passive of active withdrawals, or the use of physical violence and war. ${ }^{3 .}$

\footnotetext{
${ }^{21}$ Heidelberg Institute for International Conflict Research, at www.conflict.com/hiik/manual_en.html (last visited Nov. 20, 2001).
} 
Conflicts, therefore, could involve any number of issues. The intensity of those conflicts, however, are even more important. According to the Kosimo index, there are four levels of conflict: latent conflicts, which are completely nonviolent; crisis conflicts, which are mostly nonviolent; severe crisis conflicts, where there is sporadic use of force; and war, where there is systemic, collective use of force.

From 1989-1999, this index showed that there were 146 conflicts in the world and that 82 of them were addressed either through war or through mostly violent means. ${ }^{25}$ More interestingly, however, is examination of the particular countries engaged in conflict and the intensity of the conflict. If we compares the frequency of how conflicts are addressed with the TI index, we find that since 1975 those countries that had the least amount of corruption (i.e., those in the top quadrant of TI's Corruption Perception Index), only $12 \%$ of conflicts were addressed by mostly violent means or by warfare. Countries in the second quadrant of TI's index used mostly violent means or warfare to address $26 \%$ of their conflicts. In the third quadrant, that figure rose to $44 \%$ and in the bottom quadrant, that is the countries with the most severe corruption, it escalated to $60 \%$.

\section{Table 2}

Transparency International Quadrant

Quadrant \#1 (least corrupt)

Quadrant \#2

Quadrant \#3

Quadrant \#4

\section{Resolution of Conflicts by Violence}

$14 \%$

$26 \%$

$44 \%$

$60 \%$

${ }^{22} I d$.

${ }^{23} \mathrm{Id}$.

${ }^{24} I d$.

${ }^{25} I d$. 
We wish to emphasize that we do not mean to suggest that corruption causes violence. There are many reasons why nations go to war or why individuals and groups resort to violence within borders. $\frac{26}{2}$ There may be explanations as to why nations that are least corrupt do not result to violence to address disputes. For instance, in examining the TI chart, the countries in the top quadrant are, essentially, functioning democracies. Thus, it could well be that a functioning democracy provides the means for disputes to be resolved in a peaceful manner. 27

On the other hand, according to Fortune magazine's 100 Largest Economic Table, only three of the TI top quadrant - Iceland, Luxembourg, and New Zealand - were not large economic units. ${ }^{28}$ This might suggest that wealth precludes the need for corruption, in other words, countries that are already wealthy can afford the luxury of carefully complying with the law. This would be more persuasive if not for the fact that other countries not fairing as well on TI's index, such as China and Mexico, were ninth and thirteen respectively on the Fortune list. 29 Regardless of whether corruption causes violence or whether corruption is an indicator of something more fundamentally askew in a country, the data above show that it is at least plausible that corruption and violence are in someway linked. Corporations engaged in corruption seem to at least be in the midst of a social milieu that is prone to bloodshed. If this correlation is plausible, then the question becomes whether corporations might have a role to play in rectifying this situation.

\footnotetext{
${ }^{26}$ MICHAEL CRANNA, Introduction to THE TRUE COST OF CONFLICT: SEVEN RECENT WARS AND THEIR EFFECTS ON SOCIETY at xv, xvii (MICHAEL CRANNA ED., 1994).

${ }^{27}$ CONNIE PECK, SUSTAINABLE PEACE: THE ROLE OF THE UN AND REGIONAL ORGANIZATIONS IN PREVENTING CONFLICT 17 (1998).

${ }_{28} 100$ Largest Economic Table, FORTUNE, Aug. 5, 1996, at F-1, 5-2.

${ }^{29} I d$.
} 


\section{B. A Plausible Normative Rationale for Action}

With the exception of those industries that have a specific reason to profit from war, rarely will business people advocate for warfare for reasons of profitability. ${ }^{0}$ They may, of course legitimately be concerned with other national goals that require warfare and their businesses may profit from that warfare. ${ }^{2}$ We do not wish to diminish the economic leverage and political weight that such industries may wield in making decisions leading to military conflict. ${ }^{\text {2 }}$ Instead we pose the more narrow question of whether companies not engaged directly in producing military hardware benefit from warfare. It is at least plausible to believe that they do not.

The cost of violent conflict is large. One study shows that "every major famine in recent years has taken place in a war zone. ${ }^{, 33}$ Famine results, in large part, because of the inability to deliver foodstuffs within a war zone. These difficulties may arise either because of the danger inherent in navigating between warring armies or because the armies in control of certain areas wish to prevent delivery. ${ }^{4}$ As recently as 1994 , forty-two million people were displaced as a result of warfare ${ }^{5}$ and the impact on other social institutions, such as medical care and the legal system can be large as well. This kind of disintegration can have a direct economic impact as was the case in Kashmir, where the number of tourists dropped from 722,000 in 1988 to 10,400 in 1992.36 Moreover, with eighty percent of the population of Kashmir dependent upon agriculture, the fact that during this period, self-sufficiency was replaced with food rationing is

\footnotetext{
${ }^{30}$ See CRANNA, in THE TRUe COST OF CONFLICT, supra note 26, at 197.

${ }^{31}$ Dwight D. Eisenhower, Farewell Radio and Television Address to the American People (Jan. 17, 1961), in PUB. PAPERS OF THE PRESIDENTS OF THE U.S., 1960-61, at 1038.

32 The United States' government spent an estimated \$280.8 million U.S. dollars for defense functions in the year 2000, National Defense Budget Estimates For FY 2000, 12, at http://www.census.gov/prod/2001pubs/statab/sec.11.pdf (last visited Nov. 21, 2001), compared to the United States' $\$ 9.3$ trillion dollar GDP in the year 2000, at http://www.bea.doc.gov/bea/dnl.htm (last visited Nov. 21, 2001).

${ }^{33}$ Cranna, Introduction to THE TRUE COST OF CONFLICT, supra note 26 at XV.

${ }^{34}$ William DeMars, War \& Mercy in Africa, 17 WORLD POL'Y J., Summer 2000, at 1-10; Stephan Williams, Sudan: In From the Cold, AFRICAN BUS., July-Aug. 2001, at 42.

${ }^{35}$ Nils Bhinda, The Kashmir Conflict, in The True COST OF CONFLICT, SUPRA NOTE 26, AT 53, 63.
} 
indicative of the kind of social and economic hardship that can be experienced when conflict grips a region. 37 Even those defense industries that benefited from the conflict could conceivably have redirected their productivity toward manufacturing that could have combated poverty rather than built armies. 38 Kashmir is not an isolated case. Similar kinds of economic displacement and hardship have been chronicled in Yugoslavia, ${ }^{39}$ Sudan, ${ }^{40}$ Peru, Mozambique, ${ }^{42}$ Iraq,, 4 and East Timor.

These cases are important and suggestive. They suggest that there can be a business cost to warfare. There may also be, of course, a social and humanitarian cost as well; it is hard to think of a modern war that does not include human suffering. ${ }^{45}$ More generally, however, there exists a dialectically supporting relationship between business and sustainable peace: business needs stability to thrive and peace can be sustained through the relationships businesses build.

\section{B. Benefits For Commerce Resulting From Stability: Three Economic Reasons}

Perhaps the best way to understand the benefits that accrue to businesses by stability and peace is to look at the subject through the eyes of three influential economists: F.A. Hayek, Amrtya Sen, and Hernando DeSoto. Although each of these economists has significant ties to the United States, their global breadth (Hayek being Austrian; Sen being Indian, and DeSoto being Peruvian) makes them a diverse trio through which the importance of peace to economic

\footnotetext{
${ }^{36} I d$.

${ }^{37} \mathrm{Id}$.

${ }^{38}$ Id. at 70,74 .

${ }^{39}$ Angela Burke \& Gordon MacDonald, in The Former Yugoslavia Conflict, in THE TRUE COST OF CONFLICT, supra note 26.

${ }^{40}$ Nichale Shalita, The Sudan Conflict, in THE TRUE COST OF CONFLICT, supra note 26.

${ }^{41}$ Donald Shave, The Peru Conflict, in The True Cost OF CONFLICT, supra note 26.

${ }^{42}$ Shaun Vincent, The Mozambique Conflict, in ThE TRUE COST OF CONFLICT, supra note 26.

${ }^{43}$ Gregory Quinn, The Iraqi Conflict, in THE TRUE COST OF CONFLICT, supra note 26.

${ }^{44}$ Ian Robinson, The East Timor Conflict, in THE TRUE COST OF CONFLICT, supra note 26.

${ }^{45}$ MICHAEL I HANDEL, MASTERS OF WAR 24 (3rd ed. 2001).
} 
enterprise can be seen. Three important benefits for business can be identified through their eyes.

\section{Virtues, Stability, and Trade (Hayek)}

F.A. Hayek provides an important argument for linking ethics and trade. ${ }^{16}$ Hayek argues that integrity virtues, such as promise-keeping, truth-telling, and honesty, as well as production of high quality goods and services and enforcement of voluntary contracts, are essential to flourishing business. $\frac{17}{7}$ The reason they are important is not necessarily because these virtues are ennobling - Hayek does not pass judgment on this issue - but because they allow for an extended order based on efficient trading. ${ }^{48}$ Hayek suggests that the way to establish global ethical values and, in fact, more peaceful international relations, is to encourage international trade, because then potential trading partners can see the benefit to practicing these kinds of relationship-sustaining virtues. ${ }^{99}$ In this conceptual understanding, ethics and trade are mutually reinforcing. Integrity virtues lead to more trade and more trade demonstrates the efficacy of practicing these virtues, at least in the long run. In the short-run, however, there are always risks of individuals seeking the advantages of trade without practicing virtues that would sustain trade, which is why a governance system is required. ${ }^{00}$ Unfortunately, it is not enough to simply rely on individuals to practice these virtues.

It can be inferred from this that business is more likely to flourish when societies practice integrity virtues. As demonstrated above, however, those countries most prone to addressing conflicts through violent means are also those countries in which corruption is most prevalent. In other words, they do not practice integrity virtues. Moreover, some have noted that the

\footnotetext{
${ }^{46}$ F.A. HAYEK, THE FATAL CONCEIT (1988).

${ }^{47} \mathrm{Id}$. at 12,70 .

${ }^{48} I d .12,70-71$.

${ }^{49} I d$. at $38-47$.
} 
technologically connected global economic system is vulnerable not so much from cross-border wars, but from the actions of individuals empowered to wreak havoc on the system. Thought of otherwise, globalization requires even more attention to the practicing of integrity virtues, because the reaction against perceived injustices can be violent. For instance, the chief of network designs for Sun Microsystems, Geoff Baehr, has been quoted as saying that his "biggest worry, and it cannot be overstated, is that this entire infrastructure is very vulnerable to attack, not just from a computer hacker, but from someone getting into the telephone switches. In this world the attacker can go to the telephone front, go home and have a sandwich, and come back and attack again." ${ }^{51}$ Globalization, in fact, provides the opportunity to link society, but also provides the "super-empowered individuals who hate America more than ever because of globalization and who can do something about it on their own" with the ability to disrupt the system. ${ }^{52}$ It would seem to be a simple truism that a technologically linked world is dependent on a certain level of stability simply to be able to keep the phone lines open. Indeed Friedman notes that a stable political and economic environment is the precursor to encouraging entrepreneurship. ${ }_{3}$ Thus, if integrity virtues are a component to justice, then flourishing commerce benefits from virtuous behavior and is threatened by nonvirtuous behavior.

\section{Functioning Markets Lead to More Development of Human Beings who Can Fuel Creativity and Growth (Sen)}

A second related benefit to business from stability and peace is its enhancement of the possibility of freedom and freedom's benefits to the alleviation of marginalization as well as the flourishing of markets. The leading spokesperson for this viewpoint is Indian economist

\footnotetext{
${ }^{50} \mathrm{Id}$. at 12 .

${ }^{51}$ FRIEDMAN, supra note 8 , at 398.

${ }^{52} I d$.
} 
Amartya Sen. ${ }^{64}$ Rather than focusing on the numerical increase in trade as an indicator of development, Sen looks at the process that allows individuals, particularly the poor, to reach the potential they would have not been able to achieve had they remained in poverty ${ }^{55}$ An important reason for this emphasis is that, as Sen notes, the increase in "overall opulence" in today's global economy produces "elementary freedoms" to a large number of individuals simultaneously, perhaps even to the majority of people on the globe. ${ }^{66}$ The satisfaction of material needs allows individuals to unleash their potential and that creativity further enriches the market. In this sense, freedom results from individuals being "free" from constraint imposed by the grinding harness of poverty and from "tyranny, poor economic opportunities as well as systematic social deprivation, neglect of public facilities as well as intolerance or over activity of repressive states." ${ }^{67}$ Rather than focusing solely on economics, this is done by integrating values and economics. According to Sen,

The exercise of freedom is mediated by values, but the values in turn are influenced by public discussions and social interactions, which are themselves influenced by participatory freedoms. . . . It is important not only to give markets their due, but also to appreciate the role of other economic, social, and political freedoms in enhancing and enriching the lives that people are able to lead.

Friedman notes the consequential validity of this approach by noting that "when you put assets in the hands of the poor in a politically distorted environment, such as Liberia or Burma, not much happens. But when you put assets in the hands of the poor in reasonably stable and free environments a lot will happen." participatory freedoms empower individuals who can engage the market and enjoy its benefits.

\footnotetext{
${ }^{53} \mathrm{Id}$. at 356.

${ }^{54}$ AMARTYA SEN, DEVELOPMENT AS FREEDOM (1999).

${ }^{55} I d$. at 3 .

${ }^{56} \mathrm{Id}$. at 3-4.

${ }^{57} \mathrm{Id}$. at 3 .
} 
Values and business opportunities are thus enhanced and thereby provides a way to combat marginalization of the poor and reduces the threat of violent reaction borne of desperation.

\section{Stability From Legal Structures Can Unleash Capital (DeSoto)}

Not only does the focus on the development of freedom lead to an emphasis on governance so that freedoms can be achieved by unleashing human potential, but proper legal governance regimes can free trapped capital as well. The spokesperson for this view point is economist Hernando DeSoto. 60

DeSoto argues that the major difficulty that most of the world's poor have in obtaining the benefits of capitalism exists because countries do not have the legal infrastructure for registering proper title to real estate. This lack of legal infrastructure, for instance, makes it virtually impossible for the poor to make use of the assets they have, such as their homes, to become entrepreneurs. ${ }^{11}$ The West, he argues, takes its property law system for granted so much that it typically ignores the history of legal development where gradually governments provided reliable property documentation for ownership where title was otherwise obscured. ${ }^{62}$ Thus, the poor have houses built on land where there are no recorded ownership rights and as a result, lenders have no reliable collateral to support loans that could be used to start a business. 63

The latent economic potential of this situation is immense. DeSoto calculates that in Haiti, for instance, sixty-eight percent of those living in the city and ninety-seven percent of

\footnotetext{
${ }^{58} I d$. at 9.

${ }^{59}$ FRIEDMAN, supra note 8, at 356.

${ }^{60}$ Hernando DeSoto, THE Mystery of CAPITAL: Why CAPITALism Works IN THE WeSt AND FaILS EVERYWHERE ELSE (2000).

${ }^{61} I d$. at 6.

${ }^{62} I d$. at 8 .

${ }^{63} I d$. at 6.
} 
people in the countryside reside in homes where there is no clear legal title. ${ }^{64}$ In Egypt, the same problem arises for ninety-two percent of city dwellers and eight-three percent of the people in the countryside. 55 DeSoto estimates that the total assets held by the poor in the Third World and former Communist countries that cannot be accessed because of defective property registration systems is at least $\$ 9.3$ trillion.

The institution of property registration systems in the West, De Soto argues, required legitimizing the extant, albeit informal, rules of customs practiced by the population to provide a greater good to society by engaging in productive economic activity. The connection of this process to peace is that by doing so, the chances for social confrontation, particularly over scarce resources, are reduced and economic growth is encouraged. DeSoto argues "everyone will benefit from globalizing capitalism within a country, but the most obvious and largest beneficiary will be the poor." 67 As we have already intimated, this benefit can have direct

\footnotetext{
${ }^{64} \mathrm{Id}$. at 33 .

${ }^{65} \mathrm{Id}$. at 33 .

${ }^{66} I d$. at 35. As an analogy, DeSoto talks about the untapped potential of a mountain lake. Consider a mountain lake. We can think about this lake in this lake in its immediate physical context and see some primary uses for it, such as canoeing and fishing. But when we think about this same lake as an engineer would by focusing on its capacity to generate energy as an additional value beyond the lake's natural state as a body of water, we suddenly see the potential created by the lake's elevated position. The challenge for the engineer is finding out how he can create a process that allows him to convert and fix this potential into a form that can be used to do additional work. In the case of the elevated lake, that process is contained in a hydroelectric plant that allows the lake water to move rapidly downward with the force of gravity, thereby transforming the placid lake's energy potential into the kinetic energy of tumbling water. This new kinetic energy can then rotate turbines, creating mechanical energy that be used to turn electromagnets that further convert it into electrical energy. As electricity, the potential energy of the placid lake is now fixed in the form necessary to produce controllable current that be further transmitted through wire conductors to faraway places to deploy new production ... . Capital, like energy, is also a dormant value. Bringing it to life requires us to beyond looking at our assets as they are to actively thinking about them as they could be. It requires a process for fixing an asset's economic potential into a form that can be used to initiate additional production.

${ }^{67} I d$. at 189.
} 
consequences for sustainable peace. Klaus Schwab of the World Economic Forum recognizes that "if we do not invent ways to make globalization more inclusive ... we have to face the prospect of a resurgence of the acute social confrontations of the past, magnified at the international level. 68

It follows that the failure to avoid social confrontations is itself a threat to business. Business and peace are connected by a mutually supporting atmosphere where members of society are engaged in a market economy rather than marginalized to the point of resentment. The western property system allowed for the production of surplus value beyond what a home would otherwise represent because it became able to tap into the economic potential of the real estate itself.

The difficulty for the legal system is that if it does not keep pace with such basic natural impulses as that of building a home, it will frustratingly marginalize individuals so that they remain outside of the economic system. If this occurs, individuals will invent their own extralegal substitutes for property protection. ${ }^{0}$ This occurs now in Third World and former communist countries, but it was also the case in the West.

Rather than maintain a system that was out of touch with the norms of the people they governed, Western nations gradually began to recognize these arrangements as legitimate and

\footnotetext{
${ }^{68} I d$. at 213.

${ }^{69}$ Id. at 51 .

${ }^{70} \mathrm{Id}$. at 71 .

${ }^{71}$ Id. at 102 .
}

Law began adapting to the needs of common people, including their expectations about property rights, in most West European countries during the nineteenth and early twentieth centuries. By that time, the Europeans had concluded that it was impossible to govern the Industrial Revolution and the presence of massive extralegality through minor ad hoc adjustments. Politicians finally understood that the problem was not people but the law, which was discouraging and preventing people from becoming more productive. 


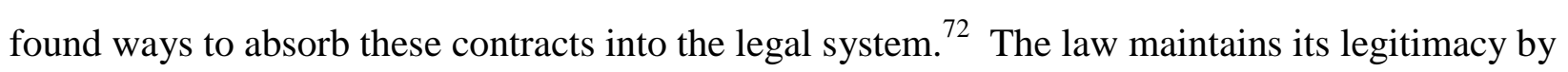
staying in touch with the norms that guide daily life. ${ }^{73}$ If the law fails to do so, those operating by those extralegal contracts will not enter the economic and legal system. "What governments in developing countries have to do is listen to the barking dogs [marking local territory] in their own communities and find out what their law should say. Only then will people stop living outside it.",

\section{Reciprocal Relationship between Business and Peace}

Business has an interest in peaceful relations for several reasons. One of the implications of the foregoing discussion is that in order to foster sustainable peace businesses will need to do more than attend to profitability. The causes of war are more multifaceted than any one business or set of businesses can eliminate, but businesses can play a role in mitigating those causes when they attend to human issues. Indeed, it is more of an ideological mantra to assume that human beings are selfish than it is a fact of human life. ${ }^{66}$ Thus, although development of wealth is an appropriate interest of business, as Sen also argues that "the usefulness of wealth lies in the things that it allows us to do - the substantive freedoms it helps us to achieve." achieving freedom is itself a moral determination and its consequential efficacy is demonstrated by Sen's finding that "no famine has ever taken place in the history of the world in a functioning democracy.,

${ }^{72} I d$. at 106.

${ }^{73} I d$. at 108.

${ }^{74} I d$. at 172.

${ }^{75} I d$. at 168.

${ }^{76}$ SEN, supra note 54, at 118 (stating that "the presumption of ubiquitous selfishness is hard to defend empirically"); see also, Timothy L. Fort \& James J. Noone, Banded Contracts, Mediating Institutions, and Corporate Governance: A Naturalist Analysis of Contractual Theories of the Firm, 62 LAW \& CONTEMP. PROBS. 163 (1999) (for an overview of anthropological indicators that human beings are more social than individual).

${ }^{77}$ SEN, supra note 54, at 14.

${ }^{78} I D$. at 16. 
The notion of democracy is that people have a voice in the laws that govern them. Not only does businesses' attention to the development of freedom reinforce the processes by which peace is achieved, but the internal dynamic by which domestic policies are created require attention to, as DeSoto puts it, listen to the "barking dogs" to understand the informal, but very real, contracts that people enter into and the appropriation of which serves to legitimize

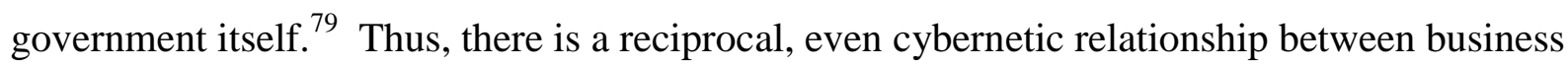
and peace, where business is benefited by stability and in order to achieve that stability, simply for purposes of business activities, requires engaging in issues of human development, in encouraging legal development of institutions such as property, and in nurturing, as Hayek would argue, for integrity virtues.

\section{Benefits of Business to Peace}

In addition to the reciprocal relationship identified above, there is also a benefit to stability through business enterprise. Recently, a symposium identified just and sustainable economic development as one of the ten practices necessary for abolishing war. ${ }^{00}$ There is considerable supportive historical sentiment. Philosophers such as Montesqeui have argued that

\footnotetext{
${ }^{79}$ DESOTO, supra note 60, at 178.

${ }^{80}$ Just PEACEMAKING: Ten PRACTICES FOR ABOLISHING WAR (GLEN StASSEN, ED.). The ten practices are: Support Nonviolent Direct Action Take Independent Initiative to Reduce Threat Use Cooperative Conflict Resolution Acknowledge Responsibility for Conflict and Injustice and Seek Repentance and Forgiveness Advance Democracy, Human Rights and Religious Liberty

Foster Just and Sustainable Economic Development

Working with Emerging Cooperative Forces in the International System

Strengthen the UN and International Efforts for Cooperation and Human Rights

Reduce Offensive Weapons and Weapons Trade

10. Encourage Grassroots Peacemaking Groups
} 
by trading, nations make it more unlikely they will go to war. ${ }^{81}$ Immanuel Kant held a similar view $\frac{82}{2}$ and it has been carried into the present age as well.

There is, however, another view. Donald Kagan, for instance, argues that the hope for lasting peace based on the emergence of a free market economy or on the basis of the history of democratic nations not fighting one another is misguided. ${ }^{64}$ Kagan warns that the "only thing more common than predictions about the end of war has been war itself." ${ }^{5.5}$ Moreover, anthropologist Lawrence Keeley's studies show that groups who trade may not fight each other in the midst of war, but they do fight each other before and after war. ${ }^{66}$ Not only was this true "before civilization" but the United States and Japan actively traded prior to the attack on Pearl Harbor and all of the combatants of World War I traded with each other before and after hostilities. 87

Nevertheless, even after undertaking his study, Keeley recommends that engagement between countries is more likely to lead to the kind of relationships where they are less likely to

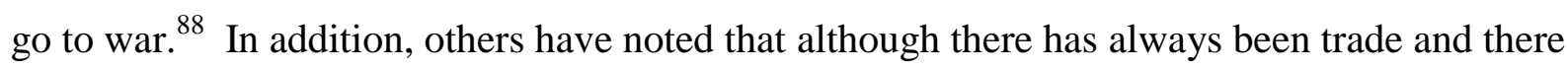
have always been multinational nongovernmental organizations, there is something unique about

\footnotetext{
${ }^{81}$ See Philip M. Nichols, Regulating Transnational Bribery in Times of Globalization and Fragmentation, 24 YALE J. INT'L L. 257, 263 (1999).

${ }^{82}$ KANT, supra note 12.

${ }^{83}$ Nichols, supra note 81 at 263. Nichols, for instance, cites evidence supporting the position that those countries that choose to trade rather than to erect barriers to trade tend to go to war less frequently. Id.

${ }^{84}$ Donald KAgAn, ON THE ORIGINS OF WAR AND THE PRESERVATION OF PEACE (1995).

${ }^{85} I d$. at 1-2. Past theories of war's obsolescence were much the same as today's theories. In 1792 the English scientist Joseph Priestley believed "the present commercial treaties between England and France, and between other nations formerly hostile to each other, seem to show that mankind begin to be sensible of the folly of war, and promise a new and important era in the state of the world in general, at least in Europe." Thomas Paine expressed a similar belief in his pamphlet The Rights of Man, which appeared in the same year: "If commerce were permitted to act to the universal extent it is capable, it would extirpate the system of war." Paine also believed, following Montesquieu and Kant, that the substitution of republics for monarchies would guarantee lasting peace ...." In 1848, John Stuart Mill sang the praises of commerce, which was "rapidly rendering war obsolete, by strengthening and multiplying the personal interests which act in natural opposition to it .... [T] he great extent and rapid increase of international trade ... [is] the principal guarantee of the peace of the world."

${ }^{86}$ LAWRENCE KEELEY, WAR BEFORE CIVILIZATION (1996).

${ }^{87} \mathrm{Id}$. at $117-22$.

${ }^{88}$ Id. at 181.
} 
this particular time and place, because "what is new is [transnational factors and organizations"] number and variety and, more significant, their challenge to the control that state actors have over world affairs.", 9

From all of this, at least three ways can be discerned in which business can contribute to peace. The first is through Track Two Diplomacy. The second is through economic development. Finally, the third is through corporate governance structures that are modeled on peaceful societies. In looking at these alternatives, we wish to stress that we are considering them in light in the most basic definitions of peace: the absence of war. As Robert Pickus has argued, evils such as oppression and starvation have their own names, but "something previous is lost when the word "violence" is blurred." Unlike Pickus, who even further wants to preserve the term "violence" for mass, organized warfare, we believe that a sense of violence in terms of the willful killing of people through acute means is a sufficiently concrete and precise enough understanding of the evil we wish to avoid so as to maintain an appropriate focus on the means by which businesses can constructively mitigate its prevalence. 1

\section{Track-Two Diplomacy Issues}

Track-two diplomacy is unofficial interaction among nonstate actors with the goal of

creating an environment in which political leaders become freer to reach accords. ${ }^{22}$ Certainly, an economic enterprise that provides benefits to two different countries embroiled in a dispute contributes to an environment where the leaders of the countries can point to the mutual advantages of resolving a conflict as a reason to avoid escalation. This is true of trade generally,

\footnotetext{
${ }^{89}$ Robert Pickus, New Approaches, in Just PEACEMAKING 235 (ZARTMAN \& RASMUSSEN, EDS. 1999).

${ }^{90}$ Pickus, supra note 89, at 231.

${ }^{91} C f .$, Id.

92 JOSEPH MONTVILlE, TRANSNATIONALISM AND THE ROLE OF TRACK-TWO DiPLOMACY 262.
} 
as exemplified in the 2001 negotiations regarding the Chinese downing of a U.S. spy plane. ${ }^{93}$ It could also occur on a more discrete level in terms of a business person who has the credibility and access to convey messages between governments without having to go through formal diplomatic channels and who may also be able to do so outside of the investigations of the media. In each of these scenarios, corporations can build relationships that cross boundaries in a way that might not be done through traditional political means. In doing so, they can provide the environment and channels for communication that might not otherwise have been there. 94 Implicit within this understanding of Track Two Diplomacy is a second element. ${ }^{55}$ Just as informal diplomacy or fostering of economic relations can create the atmosphere for political leaders to take risks, there is also an opportunity for multinational corporations to "arrest the dehumanization process between the groups in conflict, and gradually to educate the population about the human dimension of the pain and loss all sides suffer from the conflict. It is a difficult cognitive and group psychological process. ${ }^{96}$ This element is particularly appropriate for corporations because, as demonstrated below, corporations can perform this role within the boundaries of one country where there are disputes among various groups. Thus, not only may corporations play a role in diffusing conflicts between nation-states by building relationships enabling political leaders to negotiate with a government that might otherwise be considered a violent enemy, but corporations, through employment, trade, and outreach, can also "humanize" adversaries within countries to mitigate the possibilities of domestic violence as well.

\footnotetext{
${ }^{93}$ Dexter Roberts \& Rose Brady, Suddenly Beijing is Betting on Pragmatism, BUS. WK., June 25, 2001, at 55; but see, Jeff Chappell, China Trade Remains Political Issue, ELECTRONIC NEWS, Jul. 9, 2001, at http://proquest.umi.com/pqdweb? (last visted Nov. 21, 2001).

${ }^{94}$ Fort \& Noone, supra note 11 , at 518 n. 18.

${ }^{95}$ MONTVILLE, supra note 92 at 263.

${ }^{96}$ Id.
} 


\section{Economic Opportunity and Growth}

Just as there is a correlation between corruption and violence, "there is a highly positive correlation between underdevelopment and armed conflict." ${ }^{27}$ It has also, not surprisingly, been

found that war creates poverty. $\frac{28}{}$ Complaints regarding poverty are frequently involved in wars:

In many of the conflicts and revolutions in Latin America during the 1960s through the 1990s, a crucial element was the struggle of the poor for justice. This was true in Nicaragua, El Salvador, and Guatemala, in Haiti, Jamaica, and the Dominican Republic, in Chile, Brazil, and Columbia. Poverty was an important ingredient in the struggle against apartheid in South Africa, the people power revolution in the Phillipines, the troubles in Northern Ireland, the overthrow of the Shah of Iran, and the Palestinian question in Israel.

Another interpretation of the correlation between corruption and violence, is that the correlation exists because poor countries are frequently dominated by corrupt governments. ${ }_{100}$ It is because of this connection that economic assistance provided to emerging countries is typically tied to reforms. Such incentives, such as those provided by the International Monetary Fund and the World Bank, typically provide access to First World funds and markets in return for budgetary and sometimes political reform. 101

Therefore, there is the possibility that poverty contributes to warfare more than does corruption. If this is true, then it would make sense to spur economic development, even at the price of corruption, in order to reduce poverty. There is, undoubtedly, some truth to this claim. As already mentioned, there are studies demonstrating a highly positive correlation between

\footnotetext{
${ }^{97} \mathrm{~J}$. Lewis Rasmussen, Peacemaking in the 21st Century, in PEACEMAKING IN INTERNATIONAL CONFLICT 31.

98 J. Milburn Thompson: Justice And PeACE: A CHRistian Primer 58 (1998).

${ }^{99}$ Id. at 58.

${ }^{100}$ See 100 Largest Economic Table, supra note 27 at F-1, 5-2.

${ }^{101}$ David I. Oyama, World Watch, WALL ST. J., Aug. 29, 2001, at A6; India: IMF Reviewing Conditionalities, THE Hindu, Aug. 30, 2001, at 1; see also, DAVID CORTRIGHT, THE PRICE OF PEACE (1997) (analyzing the various incentives governments can use to encourage reforms that contribute to peace). As an example, Cortright cites to the economic incentives provided by the United States to Czechoslovakia from 1990-1992 which included IMF and
} 
underdevelopment and violence. ${ }^{102}$ Yet, we believe that tying violence to corruption is a more helpful indicator of a social structure more likely to beget violence. If our hypothesis is true, then multinational expansion must be justified not only upon the capacity to alleviate poverty, but to do so in a way that also mitigates corruption. We again wish to note that the link between corruption and violence requires additional research, but there are at least three initial reasons supporting our hypothesis.

First, in Amartya Sen's assessment of poverty, he describes poverty in terms of a "capability deprivation., 103 He argues that there are deprivations that are intrinsically important. ${ }^{104}$ He further contends that there are other influences on capability deprivation than low income and that the relationship between low income and low capability is variable among different communities. ${ }^{105}$ Factors influencing this variability include the age of a particular person, gender and social roles, location insofar as that location is prone to disruption due to natural disasters, famine, or violence, and the epidemiological atmosphere ${ }^{106}$ Moreover, the relative deprivation in terms of income can lead to an absolute deprivation in terms of capability because "being relatively poor in a rich country can be a great capability handicap, even when one's absolute income is high in terms of world standards." 107 In part, this relative deprivation occurs where the desire to avoid "social exclusion" creates a demand for the poor in a rich country to devote resources to the acquisition of goods, such as televisions and automobiles that would not occur in a poor country where such goods are not as widespread. ${ }^{108}$ A consequential

World Bank resources, market access in the form of MFN status, economic assistance, investment guarantees and credits, and transfer of technology in return for guarantees on the use of such technology. Id. at 105.

${ }^{102}$ Rasmussen, supra note 97 , at 31.

${ }^{103}$ SEN, supra note 54 , at 87.

${ }^{104} I d$.

${ }^{105} I d$. at $87-88$.

${ }^{106} \mathrm{Id}$. at 88 .

${ }^{107} \mathrm{Id}$. at 89.

${ }^{108}$ Id. at 89 . 
example of this, Sen writes, lies in comparing premature mortality. For example, African American men possess significantly higher income than Chinese, Indian, Sir Lankan, Costa Rican, and Jamaican men, but have "remarkably higher death rates."109 Another possible reason for these death rates might be the significantly higher level of violence that occurring in African American communities. 10

From this, Sen does not deduce that inequality should be eradicated. Rather, Sen notes that such attempts can "lead to loss for most - sometimes even for all." 111 He does, however, argue that insufficient attention has been directed to ways in which equality can be manifested, i.e., that capabilities of the poor are influenced by factors more complex than comparisons of income. In particular, he emphasizes the need for social participation and public discussion in making economic policy so as to inform such policy of the complex dynamics that foster frustration and dampen human development. 113

Second, anthropologists provide two helpful clues as to why low income is itself not explanatory. One reason is that premodern societies were relatively poorer than today's world, yet they were also less violent. Anthropologist Leslie Sponsel, for instance, argues that by studying the accumulated specimens of fossil hominids in museums and universities, one can conclude that "nonviolence and peace were likely the norm throughout most of human prehistory and that intrahuman killing was probably rare. 114 Although eschewing the notion of a prehistoric, peace-loving hominid, anthropologist Lawrence Keeley similarly concludes that adjusted for population sizes, the twentieth century killed at a rate twenty times higher more than

\footnotetext{
${ }^{109} I d$. at 96.

${ }^{110}$ See Dan Eggen, Death Penalty Foes Fault Justice Study, THE WASH. POST, June 19, 2001, at A3.

${ }^{111}$ SEN, supra note 54, at 93.

${ }^{112} \mathrm{Id}$. at $107-08$.

${ }^{113} \mathrm{Id}$. at 110 .

${ }^{114}$ Leslie E. Sponsel, The Natural History of Peace: The Positive View of Human Nature and Its Potential, in A NATURAl History of PEACE InSERT StART PAGE, AT 103 (ThOMAS GREGOR, ED. 1996).
} 


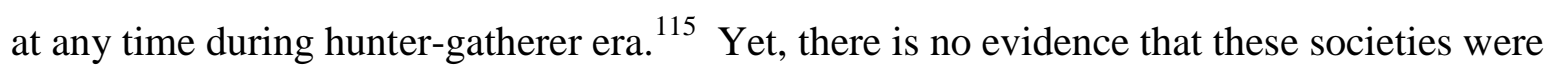
materially more prosperous than the world is today.

Sen's explanation for relative capability deprivation provides at least a plausible explanation for this. Although hunter-gatherer societies were often hierarchical, it was a hierarchy frequently based on stable environments. This is not to say that premodern societies did not experience catastrophes - they did - but they more frequently occurred as the result of natural influences such as earthquakes or volcanoes than with disruption of political and economic arrangements. 116 Change, however, produces stress than can accentuate capability deprivation in two important ways. The first way is in the sense of a loss of the capability to have control over one's life. The free market, for all its merits, directly undermines this capability. ${ }^{117}$ Unfortunately, globalization introduces stress, threat, and social change. "The bigger, fast and more influential the herd becomes, the more individual citizens start to feel that the locus of economic matters is shifting from the local level, where it can be controlled, to the global level, where no one is in charge and no one is minding the store. When all politics is local, your vote matters. But when the power shifts to these transnational spheres, there are no

\footnotetext{
${ }^{115}$ KEELEY, supra note 86 , at 93.

${ }^{116}$ But see Peter Gray \& Kendrick Oliver, The Memory of Catastrophe, HIST. TODAY, Feb. 2001, at 9, 11.

117 Ervin Staub writes that: strongly established hierarchical arrangements are potentially harmful, especially in complex, heterogeneous human societies with varied subgroups that can turn against each other. Among primates, a stable dominance hierarchy reduces violence, and this can happen in small human groups as well. Under stable conditions, hierarchical, obedienceoriented or monolithic societies maybe as peaceful as pluralistic ones. But when stress, threat, life problems, or social change bring forth leadership that moves the group toward violence against others, a multiplicity of beliefs and values makes it more likely that opposition will arise that inhibits this movement.

Ervin Staub, The Psychological and Cultural Roots of Group Violence and the Creation of Caring Societies and Peaceful Group Relations, in APPROACHES to PEACE: A REAdER IN PEACE STUdies, at 135 (DAVID P. BARASH, ED. 2000).
} 
elections and there is no one to vote for." 118 This phenomenon creates disempowerment, or to use Sen's phrase, a capability deprivation, because it deprives individuals within a community from having a sense of stability and control in their lives. The fact that no one person is responsible does not mitigate the effect because "the most arbitrary powers in history always hid under the claim of some impersonal logic - God, the laws of nature, the laws of the market - and they always provoked a backlash when morally intolerable discrepancies become glaringly visible. 119

One reaction against this kind of disempowerment occurs through fundamentalist

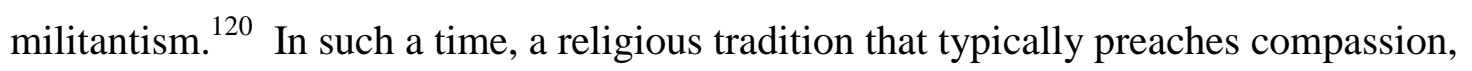
forgiveness, and tolerance can switch to messages intolerance and violence because these are not "normal times.",121

One final anthropological example demonstrates the moral difficulties, as well as the capability deprivations, produced economic change and material distributions. When Hawaii encountered the West, though the interaction with British Commander James Cook, the practice of kapu (or taboo) was part of the religious mythological system by which the Islands kept themselves in pono (or balance). ${ }^{122}$ Kapu derived from the Kumulipo, the Hawaiian creation myth and it was part of an extremely hierarchical social system so rigid that if the

\footnotetext{
${ }^{118}$ FRIEDMAN, supra note 8, at 191, quoting Stephen J. Kobring.

${ }^{119}$ ID. (quoting Yaron Ezrahi).

${ }^{120}$ R. SCOTT APPELby, THE AMBIVALENCE OF THE SACRED 58 (2000).

By shrinking time and space through communications and transportation technologies, modernity has made it much more likely that Sikhs, Buddhists, Christians, Jews, Hindus, Muslims, and nonbelievers live in close proximity to one another, especially in large urban areas around the world. In this globalized milieu, religious extremisms - the civic and violent intolerance of outsiders - has become the response of choice for a disproportionately influential minority within traditional religious communities that feel threaten by the new pluralism.

${ }^{121} I d$. at 88 .

${ }^{122}$ See AlASDAIR MACINTYRe, AfTER VIRTUE 105 (1981); see also Fort \& Noone, supra note 11, at 528.
} 
shadow of an Ali'i Nui (a noble) fell on a common person, the person had to be put to death. Nevertheless, the Moi (or king) had strict responsibility to govern for the common good and if the land was not fertile, Hawaiian religion deemed it a judgment on the gods for the lack of the Moi's purity. $\frac{124}{1}$ The difficulty with kapu, however, was that once westerners showed that kapu rules (such as violating the prohibition for men and women to eat together) could be violated without retribution and further than kapu rules could be used by Ali'i Nui to restrict new western goods for themselves to the exclusion of the common people, the notion of kapu was transformed from something that was part of a system that required reciprocal duties from all elements of society to something that was simply a rule, like "no trespassing" that was imposed on the poor without an obligation to treat them well. ${ }^{125}$ By making this kind of transformation, kapu rules created a capability deprivation for the common people. In other words, kapu rules were divorced from their communal context and simultaneously made less transparent, the combination of which creates a relative disparity that is different from simply material disparity.

Thus, it is plausible to conclude that it is not simply low income that contributes to violence, but that the ordering of social institutions, particularly in times of stress and change that can disempower individuals and thereby increase their capability deprivation. The disordering of social institutions thus can create the seeds of exploitation, alienation, and deprivation for which there are fewer "weapons" for the disadvantaged to use to claim resources necessary for development as well as creating a moral disparity by which those in power may be

\footnotetext{
${ }^{123}$ See VALERIO VALERI, KINGSHIP AND SACRIFICE: RITUAL AND SOCIETY IN ANCIENT HAWAII (PAULA WISSING TRANS., 1985) (discussing the Hawaiian religious system); see also, MARSHALL SAHLINS, ISLANDS OF HISTORY (1985).

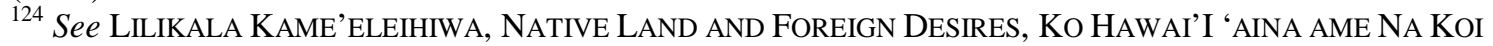
PU'UMAKE A KA Po’E HAOlE: A History OF LAND TENURE CHANGES IN HAWAII From TRADITIONAL TIMES UNTIL THE 1948 MAHELE INCLUDING AN ANALYSIS OF HAWAIIAN ALI'I NUI AND AMERICAN CALVINISTS 104-05 (1992); see also, Timothy L. Fort, Corporate Makahiki: The Governing Telos of Peace, 38 AM. BUS. L.J. 301, 342-43 (2001).

${ }^{125}$ See MARSHALL SAHLINS, ISLANDS OF HISTORY 242 (1985); see also Fort, supra note 124, at 348-49.
} 
more inclined to use violence as a way to avoid discussion as to whether the distribution of capabilities is fair. It is not simply inequality that is a problem nor is it poverty. Instead, what threatens violence is a governance mechanism that has become corrupt because it fails to allow individuals to influence in the rules that govern them.

\section{Backlash and Its Meaning}

If our analysis is correct, then the meaning of the so-called "backlash" against globalization is more comprehensible. One argument for the need for corporations to pay attention to the needs of corporate constituents, after all, is that there is a backlash against globalization. Evidence of this backlash is in protests such as in Seattle, 2,26 Davos, 2 and Quebec. $^{128}$ Similar protests against capitalism were also raised in India by Gandhi 29 and Chinese protests of British industries in the nineteenth century. $\frac{130}{10}$

It may be tempting to dismiss these protests as symbolic and ineffective. Yet, the technology that allows so much of globalization to occur also provides the mechanism for others to disrupt it. For instance, the fact that a teenager in the Phillipines can hack into computer systems and disrupt computers around the world ${ }^{131}$ illustrates the vulnerability of a networked system. Similarly, with chemical and biological weapons small enough to fit into backpacks, 32 the stakes for business to maintain peace are high. We do not wish to suggest that the actions of

\footnotetext{
${ }^{126}$ See David Postman, Resistance Takes Fast Track - Protestors Training Now for Sit-ins, Bockades, SEATTLE TIMES, Sept. 10, 1999, at A1 (describing the protests in Seattle at the meeting of the World Trade Organization). ${ }^{127}$ See David Gresing, Shades of Seattle Riot as Clinton Addresses Elite Economic Forum, CHI. TRIB., Jan. 30, 2000, at C13 (describing the protests in Davos at the annual meeting of influential business leaders held there annually).

${ }^{128}$ Anthony De Palma, In the Streets, Fervor, Fears and A Gamut of Issues, N.Y. TIMES, Apr. 22, 2001 , at A4.

129 See LOUIS FISCHER, THE LIFE OF MAHATMA GANDHI 162-76 (1950).

${ }^{130}$ See Jonathan D. Spence, The SeArCH For Modern China 117-64 (1990).

${ }^{131}$ Computer Virus Hits 14 Agencies, CHI. TrIB., May 10, 2000, at A1.

${ }^{132}$ Nerve Gas Kills 6 in Tokyo; Thousands Sickened in Suspected Terrorist Plot, CHI. TRIB., Mar. 20, 1995 , at N1.
} 
groups perpetrating these acts are doing so out of high moral principle; they may simply be thugs.

Yet, the crux of the matter is that globalization can create a sense of disempowerment as well as empowerment. Disrupting existing social structures in exchange for material development can provide the opportunity for the disempowerment of common people and for the corruption of those with the authority to gain access to wealth and suppress accountability to the common good. In a manner similar to what occurred in Hawaii, this dynamic is based on the ability to control societies and reduce accountability. Maintaining such a system, of course, is easier when there is less transparency of transactions. All of these dynamics foster corruption as well as limit the ability for nonviolent resolution of conflicts for the simple reason that transparency demonstrates unfairness. Thus, the linkage of corruption to peace makes sense because of the inability to justify the moral rationale for the disparity among a given society regarding its distribution of capabilities. The distribution is more than economic; there are also social and moral dimensions that transform a relative lack of wealth into an unjust social structure. The unjustness of a social structure is a call for reformed governance. The next section examines argues that governance of corporations, as well as nation-states, needs to be considered in a contemporary global context in order to achieve sustainable peace.

\section{THE IMPORTANCE OF GOVERNANCE}

The backlash against capitalism is quite real in that there are people demonstrating and protesting a world dominated by free markets, and more particularly multinational corporations. To some, the rioting in Seattle in 1999 or at various other meanings demonstrates the anger that 
spreading capitalism inspires, even if the reasons for the anger are very diverse. ${ }^{133}$ To others, the diversity of the grievances, ranging from protectionist labor unions, environmentalists, antisweatshop protestors, save-the-turtles activists, save-the-dolphin activists, to anti-genetically altered good activists will prevent the development of a "coherent alternative ideology."134

Yet, to think of a reaction against capitalism in the form of a clearly defined alternative framework may miss the point. What corporations operating around the world may face is not the opposition from an alternative ideology, such as communism, but rather protests against capitalism on the basis of identity and community. It is this more guerilla-like kind of locally defined opposition that makes not just political governance important, but also corporate governance. Corporations must have a mechanism within their own governance mechanism to provide the capacity to address identity-related conflicts that can be fueled by resentments resulting from disrupted local economies. Moreover, one of the strengths of the free market, its ability to be able to float freely from particular identity and religious commitments makes it more difficult to present itself as an inspiring force that local communities should embrace in overthrowing traditional ways of life.

Indeed, the difficulty of free markets is that it tends to challenge the identity of communities. $\stackrel{136}{ }$ And dealing with identity-based conflict may be the most likely kind of

\footnotetext{
${ }^{133}$ DESOTO, supra note 60, at 5.

${ }^{134}$ FRIEDMAN, supra note 8, at 334.

${ }^{135}$ As Friedman puts it, Arab nationalism, socialism, fascism or communism - while they may have made no economic sense, had a certain inspirational power. But globalization totally lacks this. When you tell a traditional society it has to streamline, downsize and get with the Internet, it is a challenge that is devoid of any redemptive or inspirational force. And that is why, for all of globalization's obvious power to elevate living standards, it is going to be a tough, tough sell to all those millions who still say a prayer before they ride the elevator. ID. at 341.

${ }^{136}$ Donald O. Mayer, Community, Business Ethics and Global Capitalism, 38 AM. BUS. L. J. 215, 226-27, 2001.
} 
problem corporations deal with and the kind of problem most likely to threaten corporations themselves.

For instance, peace research shows that mass violence is no longer waged between different states as frequently as it is within borders or about borders that states claim. $\frac{137}{1 .}$ According to one study, nearly two-thirds of 1993 conflicts could be defined as identity-based "constituting a direct challenge to existing state authority as their salient characteristic." 138 Another widely reported study shows that ninety-one percent of conflicts since the end of the Cold War have occurred within rather than across borders. ${ }_{139}$ For corporations, these statistics are meaningful because they suggest that violence is more likely to occur within the domestic settings in which corporations operate. It may be true, for instance, that business interests and business persons can serve to mitigate the likelihood of violent conflict between nation-states but as powerful as corporations are, they still are not nation-states with armies engaged in warfare. Corporations are, however, engaged in and dependent upon the relative stability of the local business environment and if they simultaneously are entities that arouse suspicion, protest, and violence. Simple self-interest requires that corporations take steps to mitigate the likelihood of violence in the countries in which they operate. More particularly, they may be able to do this by taking steps to improve the atmosphere of the countries in which they operate. As suggested by the correlation described in Section I between corruption and violence, one way corporations can do this is by adopting policies that discourage corruption. This is a notion of transparency

\footnotetext{
${ }^{137}$ J. Lewis Rasmussen, Peacemaking in the Twenty-First Century: New Rules, New Roles, New Actors Peacemaking in International Conflict, in MeTHODS \& TECHNIQUeS (I. WILLIAM ZARTMANN \& J. LeWIS RASMUSSEN, EDS., 1997).

${ }^{138} I d$. at 30 .

${ }^{139}$ PECK, supra note 27, at 9.

${ }^{140}$ See Thomas L. Friedman, How to Run the World in Seven Chapters (Review of HENRY KISSINGER, DOES AMERICA NEED A FORIEGN POLICY) N.Y. TIMES BOOK REVIEW, June 17, 2001, at 15 (arguing that China did not press harder in the controversy surrounding the downing of the U.S. spy plane in 2001 because of the multibillion dollar business interests at stake in a protracted conflict with the United States).
} 
that was an underlying theme of Section I. In addition, corporations can adopt structural policies designed to mitigate the outbreak of identity-based violence that their actions may trigger. This is a notion of community that is an underlying theme of this Section.

Before sketching why governance itself is a critical factor in developing a sense of community, it is important to also be clear as to the meaning of violence. It is possible, of course, to equate many kinds of structural injustice with violence. Given the nascent nature of the connection between business practices and peace, we focus on the clearest kind of violence: actual killing. 141

Relying on this definition does not preclude consideration of the basic needs of individuals which, if not met, could lead to actual killing. As John Vasquez writes, "peace is something that is consciously constructed and not something that just appears in the absence of violence. ${ }^{142}$ Nevertheless, our emphasis concerns the perception of business justice as it relates to actual fighting and violence rather than as it relates to structural issues in and of themselves.

\section{A. Identifying Sources of Conflict}

Attempting to determine the reasons people go to war is an exhaustive process. In particular, there is the ever-present instinct to revert to notions of justice in order to preserve peace. While this instinct is one worth preserving and pursuing, the attempt to determine an objective, universal standard of justice is a never-ending quest itself. Instead, we wish to heed

\footnotetext{
${ }^{141}$ It may be that an analysis of the connection between structural injustice and corporate behavior is opportune at another time and place, but for now, we follow the argument of Robert Pickus, who states that:

It is not, I believe, helpful in work for peace to dilute the concept of violence by stretching it to include other evils which, as in the cases of "oppression" or "starvation," have their own names. Something previous is lost when the word "violence" is blurred. The real horror or war -which is not simply the dying but the deliberate organization for killing, for engage in mass indiscriminate slaughter - is vitiated. Robert Pickus, New Approaches, in APPROACHES TO PEACE 321 (1992).
} 
Zartman's warning that "peace is sometimes the enemy of justice, and conflict can be ended only at the price of objectively fair outcomes. Such peace, so the objections go, is illusory: there is no lasting peace without justice. But justice has many referents and is ultimately subjective. A conflict resolution that perfectly combines peace and justice is rare as are as other moments of perfection in human action.

Nevertheless peace and economics research identify three key approaches that are helpful to understanding this issue and that are particularly relevant for corporations. Two theories, denoted herein as Needs Theory and Security Theory, provide a template for the identification of human interests that must be met in order to prevent the kind of dissatisfaction that can lead to conflict. They fit well, in fact, with Amartya Sen's capability deprivation thesis explored in Section I.

Needs Theory is an attempt in peace research literature to determine what needs, when they are not met, are most likely to produce grievances that lead to conflict. Zartman and Rasmussen, for instance, argue that many if not most current conflicts result from "the failure of political, economic, and social institutions to pay sufficient attention to the grievances and perceived needs of significant groups in the population." 144 identification of the relevant specific needs is difficult because those needs can change according to context and cultural setting. ${ }^{145}$ Nevertheless, there are some basic needs one can identify, such as "physical and psychological security; basic survival needs, such as food and shelter; identity needs, such as dignity and respect for distinct cultural and linguistic identity; economic wellbeing in terms of educational and economic opportunity; the need for political participation; and

\footnotetext{
142 John Vasquez, Understanding Peace in A NATURAL History OF PEACE 278.

${ }^{143}$ William Zartman, Toward the Resolution of International Conflicts, in PEACEMAKING IN INTERNATIONAL CONFLICT, supra note 97, at 16-17.

${ }^{144}$ Rasmussen, supra note 97, at 311-12.
} 
the freedom to control one's own life (for example, the panoply of democratic rights, such as freedom of speech, movement, religious preference, and association). ${ }^{146}$ Denial of these needs may result in conflict. 147

A second framework is that of security. Michael Klare identifies six sources of insecurity: income level, clean water, literacy, lack of food, lack of housing, and preventable death. $\frac{148}{1}$ This list is at least consistent with, although less expansive, than those that are identified in Needs Theory. The combination of them, however, along with Sen's articulation of five kinds of freedoms provides a set of characteristics necessary to avoid conflict. Sen's freedoms, are "instrumental" in that they lead to a telos of individual human development rather than being ends themselves. They include: (1) political freedoms, (2) economic facilities, (3) social opportunities, (4) transparency guarantees, and (5) protective security. 149

It is important to see three important attributes of the items on these lists. First, there is a set of very basic needs that are concerned with the sustainability of life itself in terms of water, food, housing, health, and preventable death. In business ethics literature, these are akin to Patricia Werhane's notion of "basic rights," protections without which life would be intolerable. ${ }^{150}$ This suggests one possible link between corporate behavior and business ethics insofar as to the extent that corporations are engaged in activities that violate basic rights, they risk sewing the seeds for violence. For example, several years ago, Green Giant moved an agricultural processing plant from Salinas, California to Irapuato, Mexico. ${ }^{151}$ The stated reason

\footnotetext{
${ }^{145} I d$.

${ }^{146} I d$. at 33.

${ }^{147}$ Id.

${ }^{148}$ Michael T. Klare, Redefining Security: The New Global Systems, in APPROACHES TO PEACE: A READER IN PEACE STUDIES 54 (DAVID P. BARASH. ED., 2000).

${ }^{149}$ SEN, supra note 54, at 10.

${ }^{150}$ Patricia Werhane, PERSONS, RIGHTS AND CORPORATIONS (1985).

${ }^{151}$ Your Job or Mine: Green Giant's Decision to Move to Mexico (Documentary video produced by the University of Michigan Business School (1991) (on file with authors).
} 
for the move was to enable production of high-quality vegetables, particularly broccoli and

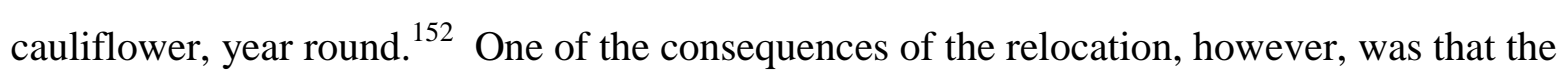
water level in Irapuato dropped to an impossible level given the resources of the local population. 153 Prior to introduction of the plant, water could be found at a depth of sixty feet. After introduction of the plant, it was necessary to drill 450 feet to find water. Fortunately, for the people of Irapuato, Green Giant arranged to have water brought in so as to alleviate the lack of clean water, but it is important to consider the animosity that would have resulted had the company simply left the local population with unclean water.

Second, there are psychological as well as physical interests at stake. These theories do not simply consider income as a need requiring some degree of stakeholder satisfaction, but also consider the level of income. They do not simply identify protection from physical harm, but also pyschological security. They do not simply identify the absence of corruption, but also the guarantees of transparency. In short, and consistent with Sen's argument from Section I, there is an important component of perception of fairness that is more illusive than what might be measurably and arithmetically counted, that serve as important interests that require stakeholder satisfaction. If these perceptions are not addressed, a perceived treatment of unfairness could be as real as actual deprivation. The relative levels of these interests and the psychological importance attached to these interests require a clear communication mechanism for articulation of how needs and interests of stakeholders are being addressed as well as a mechanism for those needs to be voiced by stakeholders themselves.

\footnotetext{
${ }^{152} \mathrm{Id}$.

${ }^{153} \mathrm{Id}$.

${ }^{154} \mathrm{Id}$.
} 
This approach is also congruent with that of stakeholder theory and social contract theory. Stakeholder theory, most prominently championed by Evan and Freeman, $\frac{155}{\text { argues that }}$ corporations should take into account anyone who is affected by a corporate action. ${ }^{156}$ While we are skeptical that corporations can, in fact, pragmatically take into account all stakeholder interests in making business decisions, ${ }_{157}$ we acknowledge that stakeholder theory provides an important insight in that the individuals most able to identify the significance of an action on a particular stakeholder is the stakeholder group in question rather than a manager attempting to hypothesize what that impact might be. ${ }^{158}$ An important reason for this, consistent with the psychological component of Needs Theory and Security Theory, is that stakeholders must perceive that important interests will be voiced and that the complaints about those deprivations will be taken seriously.

Similarly, the notion of contract theory in business ethics is based on the validity of consent of the negotiating parties. This is true in the shareholder version of contract theory, as articulated by Easterbrook and Fischel, ${ }^{159}$ who argue that corporations are simply a "nexus of contracts" for various individuals to negotiate the fulfillment of needs and desires. $\frac{160}{}$ It is also true of the social contract, such as articulated by Michael Keeley, ${ }_{161}$ Steven Salbu, ${ }_{62}$ and Thomas Donaldson and Thomas Dunfee. ${ }^{163}$ In the social contract version, consent to a norm is

\footnotetext{
${ }^{155}$ William M. Evan \& Richard Freeman, A Stakeholder Theory of the Modern Corporation: Kantian Capitalism, in ETHICAL THEORY AND Business 97, 101-05 (TOM L. BEAUCHAMP \& NORMAN E. BOWIE EDS., 3D ED. 1988). for the Best of All Worlds, 33 VAND. J. OF TRANSN'L L. 820 (2000); Timothy L. Fort, The Corporation as a Mediating Institution: An Efficacious Synthesis of Stakeholder Theory and Corporate Constituency Statutes, 73 Notre DAME L. REV. 173 (1997).

${ }^{158}$ See, Steven Cohen, Stakeholders and Consent, 14 BUS. \& PROF. ETHIC. J. 3, 13 (1996).

${ }^{159} \mathrm{See}$, FRANK H. EASTERBROOK \& DANIEL R. FISCHEL, THE ECONOMIC STUCTURE OF CORPORATE LAW (1991). 


\section{William Davidson Institute Working Paper 422}

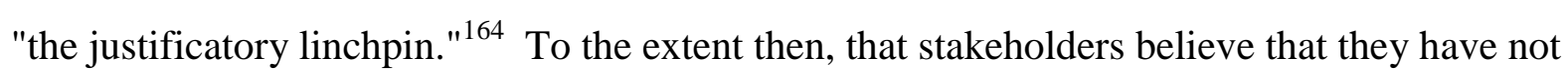
freely negotiated a contract, the more likely they would perceive an action as unfair.

The structuring of these devices plays into a governance strategy not only for communicating how corporations support local interests, but also to structure mechanisms for corporations to receive information from its stakeholders. ${ }^{65}$ The latter will need to be an institutional device and, to be actually authentic as well as perceived as authentic, the device will need to make a difference in the way corporations address the interests of local stakeholders.

Third, there is a communal aspect. Corporations will do business within particular countries and in doing so will be working with individuals who, as residents of those countries, are subject to the rivalries that exist within it. The hiring of employees, ${ }^{166}$ the location at which pollution is released, $\frac{167}{2}$ and the relocation of people in order to construct pipelines $\frac{68}{\text { have all }}$ been cited as examples of ways in which otherwise productive business enterprises can become embroiled in ethnic controversies. Moreover, to the extent that corporate behavior undermines the traditions of local communities, resentment may build toward the enterprise itself. $\frac{169}{1}$

As with the previous two implications, this approach also connects with virtue theory of business ethics because virtues are always connected to a particular community. ${ }^{170}$ What becomes particularly difficult is that virtues appropriate for a community may favor one group

\footnotetext{
${ }^{164}$ Thomas Donaldson and Thomas W. Dunfee, Toward a Unified Conception of Business Ethics in Integrative Social Contracts Theory, 19 ACAD. OF MGMT. REV. 252 (1994).

${ }^{165}$ “Needs have a greater chance of being met when relevant groups are (or perceive themselves to be) representative in the society's government; a society sharply divided into distinct identity groups may require political powersharing to meet this condition." Rasumusen, supra note 87, at 34.

${ }^{166}$ Allen Cowell, Belfast Shipyard Loses Bid to Build Queen Mary 2 and Many Jobs, N.Y. TIMES, Mar. 11, 2000, at $\mathrm{C} 1$.

${ }^{167}$ See THOMAS DONALDSON \& PATRICIA WERHANE, ETHICAL ISSUES IN BUSINESS (6th ed. Prentice Hall) (citing Gladwin).

${ }^{168}$ See Texaco in the Ecuadorian Amazon, in ETHICAL THEORY AND BUSINESS 637 (TOM L. BEAUCHAMP \& NORMAN BOWIE $6^{\text {th }}$ ed. 2001).

${ }^{169}$ See Donald O. Mayer, Community, Business Ethics, and Global Capitalism, 38 AM. BUS. L.J. 215. (2001).

${ }^{170}$ See ROBERT SOLOMON, ETHICS AND EXCELLENCE 105 (1993).
} 
over another and may also be perceived as imposing a set of western values displacing traditional values. 171

Thus, by focusing on basic needs we can see how corporations may play a role in enhancing or depriving needs. In addition, we can see that the perception of how corporations address these needs can be characterized as fair or unfair even within contemporary business ethics theories. For corporations to cope with these perceptions, they must adopt governance practices which institutionalize ethical frameworks in order to directly address needs as they arise and as they are perceived by the affected individuals who may have the capacity to violently undermine corporate activities to the detriment of both the corporation and society.

\section{B. Identity Conflict}

As we have already noted, most violence today occurs not across borders but within borders and, in particularly, among groups where identity is a critical issue. What makes identity-related conflicts especially difficult to deal with is dehumanization of those outside of one's in-group conjoined with "deeply internalized images of a moral self and diabolic enemy." 172 As this language suggests, identity-related conflicts often carry a religious element. Generally speaking, religions of all stripes value peace, but when times are not "normal," there can also be a call to contest evil. ${ }^{173}$ In response, people whose very way of life and existence can believe that "spiritual militance entails an obligation to trounce the unrighteous by whatever means necessary." 174

${ }^{171}$ See Mayer, supra note 169, at 253.

${ }^{172}$ Rasmussen, supra note 97 (citing White).

${ }^{173}$ APPLEBY, supra note 120.

${ }^{174}$ APPLEBY, supra note 120 , at 90.

The young person who joints a "fundamentalist" movement often feels, or is persuaded to believe, that the religious establishment has responded inadequately to an increasingly aggressive, secular, religiously plural, materialist, amoral ("Westoxicated"), feminist, antiorthodox milieu. 
Religious and ethnic clashes are rarely as much about battles over the efficacy of sacramental creeds as they are the selection of certain aspects of religious tradition that can be used in defense of the threatened existence and/or way of life of a particular community. $\frac{175}{\text { In }}$ addition to the potential benefits that may accrue from dialogue among religions to foster atmospheres of peace and understanding, 176 important aspect of resolving conflict exists in understanding how competition for resources can exacerbate existing rivalries. Once raised to the rhetoric of "diabolic enemy" and "evil," conflicts are far more difficult to resolve. An example can be found in environmental issues.

Thomas Homer-Dixon identifies five types of conflict that may arise in connection with environmental issues and concludes that ethnic and civil strife are the most likely forms. The first of these conflicts are those that arise directly out of local environmental degradation, such as from factory emissions, logging, or dam construction. ${ }^{177}$ The second are ethnic clashes that result from migration and "deepened social cleavages" arising from environmental scarcity. $7^{78}$

The third is civil strife when environmental scarcity affects economic productivity. The fourth relates to battles over particular environmental resources, such as water. $\frac{180}{}$ Finally, the fifth relates to conflicts between the developed and emerging worlds over addressing global

Shunning what they see as the passivity of the orthodox, fundamentalist leaders and followers transform a militant religious attitude (absolute devotion to the will of God and the demands of divine law) into an extremist tactic (naming the infidel, demonizing the other, expelling the lukewarm. The scrupulous observance of the divine law can become an ideological and operational resource for extremists. They select one aspect of the law, elevate it above others, and equate its observance to the achievement of concrete political objectives.

Id. at 90-91.

175 See Michael J. Perry, Religion in Politics, 29 U.C. DAVIS L. REV. 729, 729 (1996).

${ }^{176}$ See Council for a Parliament of the World's Religions, at http://www.cpwr.org (last visited Nov. 21 2001).

177 ThOMAs F. HOMER-DiXON, ENVIRONMENT, SCARCITY, AND ViOLENCE 5.

${ }^{178} \mathrm{Id}$.

${ }^{179} I d$. 
environmental problems such as global warming or ozone depletion. ${ }^{181}$ The reason that ethnic clashes and civil strife are the most likely is because "experts suggested that environmental pressures could "ratchet up" the level of stress, within national and international society, increasing the likelihood of many different kinds of conflict and impeding cooperative solutions." 182 Although Homer-Dixon is dismissive of some of the early research making this

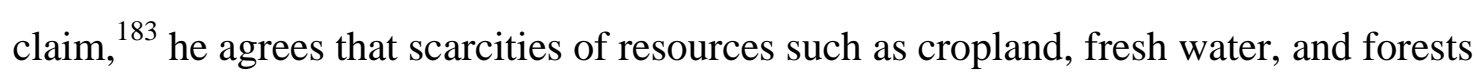
contribute to violence, especially in emerging economies, because those nations are highly dependent upon natural resources and less able to buffer themselves from social crisis. ${ }^{184}$ The reason for this violence, according to Homer-Dixon, is not simply contests over valuable resources. Instead, he claims that "scarcity by itself is neither a necessary nor sufficient cause [of violent conflict] ... it is hard to identify any cause of violence that is, by itself, either necessary or sufficient; the causes of specific instances of violence are always interacting sets of factors, and the particular combination of factors can vary greatly from case to case.,

Homer-Dixon's claim shifts the rationale for violence from that of contests over resources to structural distributions of power and resources, distributions which connect with rivalries and perceptions of injustice. He argues, for instance, that recent violence in Chiapas, South Africa, Pakistan, the Phillipines, and Haiti are connected to environmental scarcity. ${ }^{[86}$ But scarcity does not simply result from environmental devastation. Instead, "scarcity is often caused by a severe

\footnotetext{
${ }^{180} \mathrm{Id}$.

${ }^{181} \mathrm{Id}$.

${ }^{182}$ Id. at 4.

${ }^{183} \mathrm{Id}$. at 4.

${ }^{184} \mathrm{Id}$. at 12 . Homer-Dixon notes that "over 40 percent of people on the planet - some 2.4 billion - use fuelwood, charcoal, straw, or cow dung as their main source of energy; 50 to 60 percent rely on these biomass fuels for at least some of their primary energy needs. Over 1.2 billion people lack access to clean drinking water; many are forced to walk far to get what water they can find." Id. at 13. In these kinds of environments, threats to natural resources threaten the minimal resources that the local population, relying on them, cannot afford to endure.

185 Id. at 7

${ }^{186} \mathrm{Id}$. at 7.
} 
imbalance in the distribution of wealth and power that results in some groups in a society getting disproportionately large slices of the resource pie." ${ }^{187}$ In these instances, powerful groups controlling a political structure use their power to redirect laws in their favor. $\frac{188}{\text { This kind of }}$ scarcity, which he calls structural scarcity can be contrasted with ecological marginalization in which an "imbalance of resource distribution joins with rapid population growth to drive resource-poor people into ecologically marginal areas, such as upland hillsides, areas at risk of desertification, and tropical rain forests." ${ }^{189}$ Even so, just as famines do not occur in functioning democracies because those affected have a voice and a power to demand political redress $\frac{190}{\text { so }}$ also environmental scarcity is itself an "indirect cause of violence, and this violence is mainly internal to countries."

Homer-Dixon argues that there are ways to address these kinds of resource competitions. He argues that to avoid "Malthus-predicted catastrophes" one must address "ingenuity, market pricing, and quality of institutions." 1922 Technical ingenuity addresses resource extraction in the physical world, but depends on the infrastructure, such as education, that produces the scientists and engineers who can address these physical problems. ${ }^{193}$ Thus, social ingenuity -- the creation, reformation, and maintenance of public and semipublic goods, such as markets, funding

\footnotetext{
${ }^{187}$ Id. at 15.

${ }^{188} \mathrm{Id}$. at 15 .

${ }^{189}$ Id. at 16. Using water as an example, Homer-Dixon writes that "taking the world as a whole, the number of people living in countries with water stress or chronic water scarcity in 1997 was about 430 million; by the year 2025, using the UN's medium population projections, the number is expected to rise to 3 billion, or over a third of the planet's population." Id. at 67. Yet, "water scarcity rarely causes interstate wars. Rather its impacts are more insidious and indirect; it constrains economic development and contributes to a host of corrosive social pressures that can, in turn, produce violence within societies." Id. at 69.

${ }^{190}$ SEN, supra note 54.

${ }^{191}$ HOMER-DIXON, supra note 177, at 18-19. Homer-Dixon notes that "Although greenhouse warming and ozone depletion have caught the Western public's attention over the last decade, certain terrestrial and aquatic environmental trends - such as rising cropland scarcity, tropical deforestation, rising freshwater scarcity, and depletion of fish stocks - deserve equal attention. Such problems will probably, in fact, interact with and multiply the effects of atmospheric change; and they merit immediate concern because they are already seriously threatening the well-being of many developing societies." Id. at 63.

${ }^{192}$ HOMER-DIXON, supra note 177, at 28-31.
} 
agencies, educational and research organizations, and effective government "is thus a precursor

to technical ingenuity." 194 These social institutions are issues related to governance and the importance of governance to sustainable peace is the next subject.

\section{The Importance of Governance}

In the global economy, no one is really in charge. With free markets, powerful and inexpensive communication, and no world government, people, capital, and ideas can all float across borders. It is tempting to think that, in this environment, government and governance matter less. In fact, the opposite is true. As Friedman puts it:

In the era of globalization it is the quality of the state that matters. You need a smaller state, because you want the free market to allocate capital, not the slow bloated government, but you need a better state, a smarter state and a faster state, with bureaucrats that can regulate a free market, without either choking it or letting it get out of control.

Governments of nation-states which are able to provide this kind of balanced, regulatory environment generally provide transparency so that decisions can be made by those with capital, labor, and ideas to know where they want to invest their talents. $\frac{196}{1}$ This has been the story of the successful emerging economies, such as Poland, which have not simply opened their doors to

\footnotetext{
${ }^{193}$ HOMER-DiXON, supra note 177 , at 110.

${ }^{194}$ HOMER-DIXON, supra note 177, at 110.

195 FRIEDMAN, supra note 8, at 158.

${ }^{196}$ See Fort \& Noone, supra note 11, at 521-22. We use the word "talents" here in a frankly, biblical sense to connote the variety of valuable assets that individuals may possess from capital to unique capabilities.
} 
free markets, but have also undergirded free markets with legal structures that protect capital and contracts.

Not only do nation-states require good governance practices that blend transparency with institutions that protect property and contract, but as Connie Peck argues many levels of governance structures are necessary to support sustainable peace. ${ }^{108}$ It is not just any kind of governance that contributes to sustainable peace, but what Peck calls "good governance" whose linchpin is a participatory structure. ${ }^{199}$ Such a structure has benefits of fairness that reduces the likelihood of grievances growing into major flashpoints of conflict. ${ }^{200}$ What reduces that likelihood is the capability of people "to determine their own priorities; safeguard and promote their civil, political, economic, social, and cultural rights; and provide a pluralist environment, within which they can live with one another in peace, with the freedom to develop in all ways. 201 This premise that democratic systems contribute to sustainable peace is not promoted simply because it is the dominant governance system of the West, which if adopted, would bring an end to ideological battle, 202 but rather because inherent within democratic processes are inevitable checks which limit the ability for a fundamentalist obsession with the one or two points of ideological differences that cannot be comprised and, as a result, lead to war.

As R. J. Rummel writes, “democratically free people are spontaneous, diverse, and pluralistic. 203 Because they are truly pluralistic, people will belong to different interest groups,

${ }^{197}$ See Peter Finn, For This President Bush, A NEWLY BOOMING WARSAW, THE WASH. POST, JUNE 16, 2001, AT A17; SEE ALSO, Hayek supra note 46, at 137 (arguing that the societies that are historically successful and in fact the religions that endure are those that protect family and property).

${ }^{198}$ PECK, supra note 27.

${ }^{199} I d$. at 17.

${ }^{200} \mathrm{Id}$. at 17.

${ }^{201} I d$. at 17.

${ }^{202}$ See FUKAYAMA, THE END OF HISTORY AND THE LAST MAN who argues that with the fall of communism, there is an "end of history" in which ideological battles have now been won by liberal democracies.

${ }^{203}$ R.J. Rummel, Political Systems, Violence, and War, in APPROACHES TO PEACE, supra note 141, at 354. 
which will pull them in different directions. ${ }^{204}$ This creates "cross-pressure" so that "the very strong interests that drive people in one direction to the exclusion of all others, even at the risk of violence, do not develop easily. And if such interests do develop, they are usually shared by relatively few persons. That is the normal working of a democratically free society in all its diversity is to restrain the growth across the community of that consuming singleness of view and purpose that leads, if not frustrated, to wide-scale social and political violence. ${ }^{205}$ On the other hand, a totalitarian structure is not spontaneous but commanded. ${ }^{206}$ This creates, in Rummel's words a "management-worker, command-obey division" with the kind of bureaucratic organizational system that incorporates "coercive planning, plethora of rules, lines of authority from top to bottom" that ultimately polarizes major interests. ${ }^{207}$ In short, a command-control, hierarchical oriented society fosters the milieu for polarized interests, which are more difficult to be compromised, a finding validated by anthropologists, who have concluded that "strong respect for authority and the tendency to obey authorities is another predisposing characteristic for group violence. Given this characteristic, in the face of difficult life conditions or external threat members of the group will be more dependent on guidance by authorities."

A key preventative mechanism for developing the hostility that leads to violence then is the prevalence of at least participatory institutions so that individuals, have the legal infrastructure that permits them to develop their capabilities as they see fit. Certainly, this is the case on the national level. Peck argues, however, that "good governance must be instituted at all levels of society - local, national, regional, and international." ${ }^{209}$ Does this need for participatory

\footnotetext{
${ }^{204} I d$.

${ }^{205} I d$. at $354-55$.

${ }^{206} I d$.

${ }^{207} \mathrm{Id}$.

${ }^{208}$ Staub, supra note 117 , at 135.

${ }^{209}$ PECK, supra note 27, at 17.
} 
structures also apply to corporations? In one sense it does. Friedman, for instance argues that in order to obtain better governance even without a global government to fix issues such as the environment, human rights, and worker conditions, it is necessary for activists "to compel companies to behave better by mobilizing global consumers through the Internet." ${ }^{210}$ This "network solution for human rights" depends on " bottom-up regulation" that empowers the bottom, "instead of waiting for the top, by shaping a coalition that produces better governance without global government. 211

Friedman's approach relies on an opposition to the practices that business corporations would otherwise undertake. It may be the most currently pragmatic approach to take. We would like to explore, however, the reason why it would be beneficial for corporations to undertake a participatory governance policy.

\section{The Importance of Corporate Governance}

There is a tendency in contemporary business strategy that, as long as one operates within the bounds of the law, one is free to engage in any business practice that does not harm the selfinterest of the company. ${ }^{212}$ Implicit in this understanding of corporate social responsibility is the notion that other societal institutions are in place to protect interests that require protecting so that it is not the responsibility of a corporation to be concerned with these issues. $\frac{213}{\text { In addition, }}$ the argument goes, if stakeholders wish corporations to behave otherwise, the market will send the appropriate signals so that corporations change their behavior. ${ }^{214}$ Even prominent business ethicist/corporate governance scholar, Thomas Dunfee, has expressed sympathy for this

\footnotetext{
${ }^{210}$ Id. at $206-07$.

${ }^{211}$ Id. at 206-07.

212 See Fort \& Schipani, supra note 157, at 842-45.

${ }^{213}$ Id. at n.65.
} 
viewpoint in arguing that embedded within markets are moral preferences which, provided they are expressed, provide incentives for corporations to take into account the impact of actions on corporate stakeholders. 215

This approach might be denoted a balance of power approach. There is an inherent balancing mechanism in this approach that prevents corporations from unduly exerting their influence to the detriment of others who participate in that market. Corporations are thus able to pursue their self-interest attentive only to the market, which will send them the appropriate information regarding whether consumers value the corporation's actions. 216

Generally speaking, we endorse this notion of corporate responsibility. We have previously taken the position, in fact, that stakeholder theory asks corporations to do too

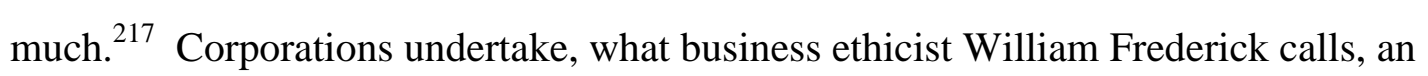
economizing function. ${ }^{218}$ By this, Frederick means that in all aspects of life, to combat entropy, it is necessary to convert resources into useful materials and energy. ${ }^{219}$ When corporations do this well, they are rewarded with profitability. ${ }^{220}$ Corporations cross borders and establish relationships that might not otherwise exist and in doing so, they provide the opportunity and frequently raise standards of living for the societies in which they are located. ${ }^{221}$ Yet, there are at least three reasons why one might be skeptical of the sufficiency of the balance of power analogy.

\footnotetext{
${ }^{214}$ See e.g., Fort \& Schipani supra note 157, at 836 (discussing the basic tenets of contractarianism).

215 Thomas W. Dunfee, Corporate Goverance in a Market with Morality, 62 LAW \& CONTEMP. PROBS. 129 , 139-43 (1999).

${ }^{216}$ See e.g., MILTON FRIEDMAN, CAPTIALISM AND FREEDOM 15 (1962).

${ }^{217}$ Fort, supra note 161, at 202.

${ }^{218}$ William C. FREDRICK, VALUES, NATURE AND CUlture IN THE AMERICAN CORPORATION 25 (1995).

${ }^{219} I d$. at 29. This is true in terms of photosynthesis as well as metabolism. In a sense, corporations act as society's metabolism because they convert resources into useful materials and energy.

${ }^{220}$ See e.g., Roberta Romano, A Guide to Takeovers: Theory, Evidence, and Regulation, 9 YALE J. ON REG. 119,119 (1992).

${ }^{221}$ Martin Crutsinger, Greenspan Warns of Protectionism, THE WASH. POST, Apr. 5, 2001, at E3.
} 
First, while markets provide information regarding the views of various economic actors, it is unclear whether markets convey adequate breadth of information. Material goods and services are easily quantifiable whereas less tangible notions are less susceptible to arithmetic quantification. How does one quantify the value of a just peace? This, in fact, is one response provided by religious leaders, for instance, in critiquing balance of power conceptions of national security. The National Conference of Catholic Bishops, for instance, have argued that peace is not the result of the balance of power. ${ }^{222}$ In their approach, peace contains an ineliminable aspect of justice that is different from the equilibrium produce by a set of competing interests. 223

The work of a balance-of-power scholar, Henry Kissinger, reveals an even more pragmatic rationale for the dangers inherent in such an approach. Kissinger describes the balance of power that the Concert of Europe, which successfully maintained almost uninterrupted peace from 1848 until 1914, as one based not only on an equilibrium of national power within Europe, but also based on a "moral element of moderation," particularly linking three Eastern powers of Prussia, Austria, and Russia. ${ }_{224}$ This moderation muted the contests for geopolitical and ethnic dominance for many decades so much that Austria muted its claims to its next-door Balkan nations while Russia soft-pedaled its identification with the same countries who shared ethnic identity. $\frac{225}{2}$ Eventually, however, the moderation between these countries was jettisoned in exchange for a rawer form of pursuit of power for national self-interest. $\frac{226}{\text { The }}$ resulting realpolitik eventually produced an insecurity and desperation for power that resulted in the kind of polarization of interests and alliances that led to World War I. ${ }^{227}$

\footnotetext{
${ }^{222}$ National Conference of Catholic Bishops: The Challenge of Peace: God's Promise and Our RESPONSE 21 (1983).

${ }^{223} I d$.

${ }^{224}$ HENRY KISSINGER, DIPLOMACY 102 (1994).

${ }^{225} \mathrm{Id}$. at 94 .

${ }^{226} \mathrm{Id}$.

${ }^{227} \mathrm{Id}$. at 103 .
} 
The import of this analogy is that reliance upon a balance of power, shorn of moral moderation, risks polarization of interests that ultimately fails to value all the interests in the market itself. In a sense, this kind of competition for market supremacy is akin to fundamentalist notions in which one criterion for success such as profitability or market-share is singled out to the exclusion of other interests. And just as militant, religious fundamentalism leads to the polarization of interests that make it impossible to compromise, so too, a single-minded obsession with profitability can lead to ignoring other values that human beings value, but which appear less compelling in a fundamentalist viewpoint. A company, for instance, insistent upon profitability may be willing to substantially contribute to the corruption of a given country in order to obtain market share and profitability. Yet, for a corporation to do this, it engages in the social milieu that is correlated with violent resolution of conflicts.

A third reason for being skeptical about the persuasiveness about a marketplace, balance of power model for corporate behavior is simply that it may well be unsustainable for business purposes. If corporations contribute to corruption of a given country in order to produce shortterm profitability, it may well also sew the seeds for opposition to that company's actions within

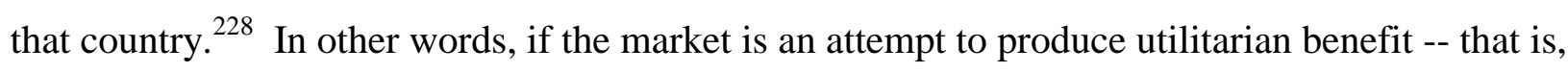
the greatest happiness for the greatest number of people -- then E.F. Schumacher's warning is telling. Schumacher, in something of a cult classic, argues that a person "driven by greed of envy loses the power of seeing things as they really are, of seeing things in their roundness and wholeness, and his very successes become failures. ${ }^{, 229}$ The foundations of peace, Schumacher argues, cannot be attained by cultivating drives such as greed and envy, because those drives

\footnotetext{
${ }^{228}$ See Jonathan Berman, Boardrooms and Bonds: Strategies of MultiNational Corporations in Conflict Areas, HARV. INT'L REV.

${ }^{229}$ E. F. SCHUMACHer, SMALl is BeAUTIFUl: ECONOMICS AS IF PeOPle MATTERed 21 (1973).
} 
"destroy intelligence, happiness, serenity, and therefore the peacefulness of man. ${ }^{230}$ Although the rhetoric and political philosophy is diametrically opposed, even free market theorist F.A. Hayek would seem to agree, because he too argues that virtues must be taught by religious and other institutions in order for individuals to value moral notions such as truth-telling, honesty, and promise-keeping that sustain the market itself.

\section{E. Why Corporations Should Incorporate Peace as a Telos}

A starting point for why corporations should consider incorporating peace as a governing teleological goal lies, surprising, in the realist and neorealist notion of foreign relations. As Donald Kagan assesses, realists believe that states and nations seek as much power as they can whereas neorealists understand the behavior of states in terms of security. ${ }^{232}$ The notion of security connects with governance, in that "the evidence suggests that the most secure are those that provide the greatest human security to their populations. Weak states are those that either do not, or cannot, provide human security." ${ }^{233}$ Moreover, this very weakness may lead political elites into a vicious cycle that further weakens their security and that of their people. Securing the interests of the people requires responding to human needs, and thus

involves the institutionalization of participatory processes in order to provide civil and political rights to all peoples. It requires adequate legal enforcement and judicial protection to ensure that all citizens are treated equally and fairly and that their human rights are safeguarded. It involves equitable economic development and opportunities so that economic and social rights can be provided. Finally, it entails the development of pluralistic norms and practices that respect the unique cultures and identities of all. Sustainable peace also requires education of dominant groups to convince them that their own long-term security interests lie in

\footnotetext{
${ }^{230} \mathrm{Id}$.

${ }^{231}$ HAYEK, supra note 45.

${ }^{232}$ DONALd KagAN, ORIGINS OF WAR 6-7 (1995).

${ }^{233}$ PECK, supra note 27, at 16.
} 
the development of a just society.

In this light, there may be a self-interest for corporations to undertake action that might alleviate the pressures that cause conflict if for no other reason than to limit the likelihood of the "angry empowered person" of which Friedman writes. ${ }^{235}$ More generally, we suspect that if the correlations and arguments we have found supporting these correlations are true and understood, there may be a genuine interest among corporate leaders to aspire to orient policies in order to mitigate the likelihood of bloodshed.

We do not advocate an international law that requires corporations to alter their governance practices. As Myles McDougal writes, “in pluralistic and rapidly changing communities, rules are always complementary ambiguous, and incomplete .... The conception of "international law" as a body of rules regulating the interrelations of nation-states is doublymyopic. ${ }^{236}$ Beyond the infirmities of its over-estimating of the potentialities of rules, it has infirmities in the scope of the activities it seeks to make subject to law." 237 Rather than taking a deontological approach that mandates duties for corporations, we want to suggest a reflexive model that allows corporate boards to add an additional criterion to that of increasing shareholder value: that of aiming toward sustainable peace. There are five reasons for this approach.

First, clear aims are important for establishing ethical governance mechanisms designed to foster peace. Two business ethicists with training in psychology demonstrate the importance of this. David Messick notes that psychological studies demonstrate the unsurprising finding that human beings tend to value their own self-interest over that of others. ${ }^{2.38}$ Because of this

\footnotetext{
${ }^{234}$ PECK, supra note 27, at 45.

${ }^{235}$ FRIEDMAN, supra note 8.

${ }^{236}$ Myres S. McDougal, Law and Peace, in APPROACHES TO PEACE, supra note 117, at 134.

${ }^{237} \mathrm{Id}$.

${ }^{238}$ David M. Messick \& Max Bazerman, Ethical Leadership and the Psychology of Decision Making, SLOAN MGMT. REV. 9 (1996).
} 
tendency, Messick argues that clearly identified ethical principles provide a check against individuals simply acting in their self-interest. ${ }^{239}$ Ethical principles create a distance that makes individuals think about additional consequences to their actions beyond what an individual who wants to undertake a particular act might recognize. 240

The same holds true in corporations. If the only criterion for success is increasing shareholder value, then it is more difficult for other considerations, which may have an impact on profitability in the long-term, to enter into a decision-maker's calculus. $\stackrel{241}{ }$ One commentator has argued that the corporate constituency statutes, which have been passed in twenty-eight states in the U.S. and which generally allow managers to take into account the impact of actions on nonshareholder constituents are superfluous because a well-run company must always take such stakeholders into account. ${ }^{242}$ The difficulty, however, is that not all companies are wellrun; they may not take nonshareholder constituencies into account. ${ }^{243}$ What a clearly identified responsibility to stakeholders does is to make it more likely that such interests will be considered.

Indeed, a clearly identified goal has also been called an "aim" by another business ethicist, Joshua Margolis. ${ }^{244}$ Margolis argues that psychological study shows that a clearly defined "aim" acts to discipline the mind so as to hold it accountable. ${ }^{245}$ This Aristotelian notion suggests that corporations must do more than be aware of the possibility that their actions could contribute to a social milieu that fosters violence and, to the extent that they wish to avoid

\footnotetext{
${ }^{239} I d$.

${ }^{240} \mathrm{Id}$.

${ }^{241}$ See La Rue Tone Hosmer, Why Be Moral? A Different Rationale for Managers, 4 BUS. ETHIC. Q. 191 (1994).

${ }^{242}$ Joseph Biancalana, Defining the Proper Corporate Constituency: Asking the Wrong Question, 59 U. CIN. L. REV. 425 (1990); William J. Carney, Does Defining Constituencies Matter?, 59 U. CIN. L. REV. 385 (1990).

${ }^{243}$ Fort, supra note 157.

${ }^{244}$ Joshua Margolis, Psychological Pragmatism And the Imperative of Aims: A New Approach for Business Ethics, 8 BUS. ETHIC. Q. 409 (1998).

${ }^{245} I d$.
} 
contributing to bloodshed, establish a goal, an aim, or a telos that commits the corporation to practices that lead to the achievement of that goal. In doing so, corporations may be aspiring for more than one goal. To some, this is dangerous because it requires the corporation to serve "too many masters." ${ }^{246}$ Yet, well-run corporations already serve masters of shareholders, public opinion, bondholders and other stakeholders: "serving multiple masters is part of the job.",247 More concretely, even shareholder value proponents Daniel Fischel and Frank Easterbrook note that the New York Times is free to pursue goals of profitability as well as journalistic excellence. ${ }^{248}$ Thus, in addition to the probability that adding peace as an ethical, governing aim will be in the long-term interest of the corporation, it is also something that is within the capabilities of the corporation.

Second, this raises the question of the role of law. As we have indicated, we do not advocate an international law requiring corporations to adopt this kind of telos. We suggest that there be an opportunity for corporations to include peace as a goal and, perhaps, even to encourage that corporations do so through various domestic and international incentives. Domestically, this could be in the form of tax incentives and internationally, it could be in the form of trade benefits. The difficulty with a law that mandates specific rules, however, is the diversity of communities. Even natural law, which "did achieve conceptions of a larger community of humankind and of a common human nature and, hence, ma[d]e immense contribution to the development of transcommunity perceptions of law" also tends to attempt to apply ethnocentric interpretations of the natural law as a universal principle when there can be a diversity of belief concerning the evidence supporting the prescription. ${ }^{249}$ It is important to

\footnotetext{
${ }^{246}$ See Fort, supra note 157 , at 180.

${ }^{247} \mathrm{Id}$.

${ }^{248}$ FISCHEL \& EASTERBROOK, supra note 157 , at 36.

${ }^{249}$ McDougal, supra note 236, at 138-39.
} 
identify overarching aspects of human nature and human events, but it is also important to do so in a way that does not disempower individuals in particular communities. The characteristics of good governance that we have already identified stress the importance of individuals within a community to voice their concerns. Thus, the level of overarching governance structure is one which allows for that kind of contribution from those affected by a corporate action rather than a model that is not open to the fluidity of those voices.

There is a question, in fact, as to just how much law individuals really need. Gandhi, a British-trained lawyer for instance, thought that ninety percent of our people did not need to be governed. ${ }^{500}$ The only people who required governance were the top five percent, comprised of the avaricious, the hoarders, and the black marketers, and the bottom five percent, comprised of common thieves, the murderers, and the gangsters. ${ }^{51}$ Rather than attempt to provide specific rules for all individuals, a corporate governance regime could, however, provide a forum by which individuals can have a voice in their own affairs while coercively protecting against the mere few who may cause problems.

The third reason why it is important for corporations to consider pursuing peace as part of their business identity relates to the power of corporations generally. We do not wish to confuse economics and politics. Nevertheless, it is hard to dispute that multinational corporations are powerful. A central premise of democratic institutions is that power requires checking; otherwise that power can do evil as well as good. ${ }^{252}$ In an advanced nation-state, an effective government may check corporate power, ${ }_{53}$ but when a large multinational corporation does business in an emerging market, the relative power of the corporation vis-à-vis the government

\footnotetext{
${ }^{250}$ Ved Mehta, MahatMa GANDHI \& His APOSTLES 214 (1977).

${ }^{251} I d$.

${ }^{252}$ Friedman, CAPITALISM AND FREEDOM, supra note 216, at 3.
} 
suggests that governmental regulation of business may be insufficient to prevent corporate misconduct. 254

Thus, we believe it is important for individuals to have the opportunity to voice concerns regarding issues that affect them. It is this voice that is important more so than the particular organization to which the voice is directed. The relative power of corporations requires checks and if those checks cannot be achieved through external regulation, then there is a reason to modify corporate governance regimes so as to provide internal checks.

Fourth, peace literature and psychological research emphasize the importance of doing. In corporations, people work side-by-side with others with whom they may not otherwise have an association. Sociologist Ronald Takaki, for instance, argues it is at work that Americans encounter diversity they may not find in neighborhoods, churches, families, and voluntary

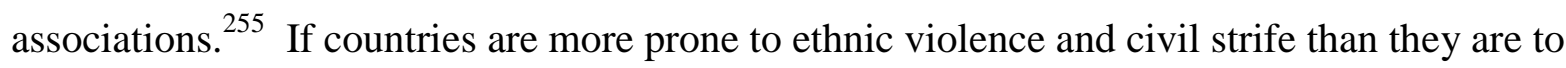
cross-border warfare, then a business can serve as a place where individuals can make connections with those of other identities that they might not otherwise have made. This can have an important psychological and consequential effect. Ervin Staub reports that psychological research shows that people learn by doing. As people help or harm others, they become increasingly helpful or capable of inflicting increasing harm .... The evolution of helping and harming is also apparent in real life. Many heroic rescuers of Jews in Nazi Europe started out intending to help an acquaintance for a short time, but then became increasingly helpfuland committed. Helpful actions create psychological change in the actor. 256

\footnotetext{
${ }^{253}$ Cf. CASS SUNSTEIN, REPUBLIC.COM (2001) (warning about the influence of corporate power even in places like the United States as demonstrated through debates over campaign finance reform).

${ }^{254}$ See, e.g., Gladwin in ETHICAL ISSUES IN BUSINESS (Thomas Donaldson and Patrica H. Werhane, eds. 6th ed.) (noting the influence of Shell on the government of Nigeria).

${ }^{255}$ RONALD TAKAKI, THROUGH A DIFFERENT MIRROR: A HISTORY OF MULTICULTURAL AMERICA 426 (1993).

${ }^{256}$ ERVIN STAUB, NATURAL HISTORY OF PEACE 140.
} 
Business organizations provide a place where individuals can develop face-to-face relationships with others. They can form a sense of community with those that they previous did not know. This kind of learning-by-doing has roots in other kinds of peace-related projects. For instance, the "Seeds of Peace" program annually brings approximately four hundred Arab and Israeli teenagers to Maine. ${ }^{\sqrt[527]{7}}$ One of the first steps is simply to give the enemy a face. ${ }^{\sqrt[58]{ }}$ Doing so, by creating personal relationships, breaks through stereotypes, 2,29 and doing so creates a sense of community with individuals who have a stake in the preservation of that community. 260 Further, giving youngsters a voice, that is the opportunity to speak, empowers them. 61

The fifth reason that corporations should include peace as a corporate goal is that it creates a sense of community. Aristotle long ago emphasized the connection between individual virtue and the role of the community in forming the moral character of someone who possessed excellent virtue. $\frac{262}{}$ A community is held together by a common goal or set of goals. $\frac{63}{\text { If people }}$ learn by doing, as we have just described, then the doing that occurs within an organization will

257 John Wallach, The ENEMy Has A FACE: The SEeds of PEACE EXPERIENCE 3.

${ }^{258} \mathrm{Id}$. at 7.

${ }^{259} I d$. at 39.

${ }^{260} \mathrm{Id}$. at 7.

${ }^{261} I d$. at $52-53$.

Empowering, even if you don't change another person's opinion, is literally giving somebody a voice. A voice doesn't mean that you always get heard. In the adult world, we don't always get heard. But sometimes we simply need to speak. This sense of empowerment is an important set for the youngsters. They are able to move beyond self-pity and come closer to acknowledging their own role in the conflict. They are forcing the people around them to understand their pain, even to experience it. Yet if the youngsters themselves don't re-experience the pain as well, they simply force it onto other people, they are not able to make a connection between their suffering; they only reaffirm the righteousness of their own cause. As long as they continue to pursue that argument, they remain closed to the other side. The youngsters are not accepting or acknowledging what those around them have to share.

${ }^{262}$ ARISTOTLE, NICHOMACHEAN ETHICS (Martin Ostwald, trans. 1962); ALASDAIR MACINTYRE, AFTER VIRTUE (1981); ROBERT SOLOMON, ETHICS AND EXCELLENCE: COOPERATION AND INTEGRITY IN BUSINESS (1993); Jeffery Nesteruk, Law and the Virtues: Developing a Legal Theory for Business Ethics, 5 BUS. ETHIC. Q. 361 (1995); Bill Shaw and John Corvino, Hosmer and the 'Why Be Moral' Question, 6 BUS. ETHIC. Q. 373 (1996).

${ }^{263}$ AMITAI ETZIONI, THE NEW GOLDEN RULE (1996). 


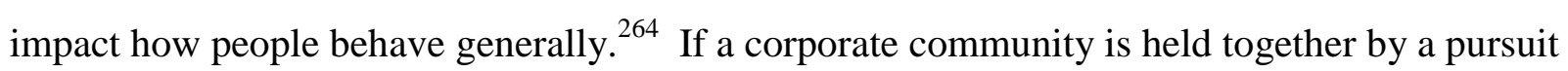
of profit that rationalizes corruption and abuse, that culture is bound to have deleterious effects on individual behavior. The nature of the corporate community is, in fact, the critical link between ethics and governance because it is in the governance of a community that certain kinds of behaviors are produced, whether for the good or not. Thus, it is important to specify more clearly the attributes a corporation would possess if it is to link governance, ethics, and sustainable peace.

\section{CONCLUSION}

Anthropologists have studied the attributes of peaceful societies and these studies provide an understanding of what a corporate community that fosters peace may look like. Leslie Sponsel, for instance, in studying ethnographies of the Semai, Chewong, Buid, and Piaroa peoples concludes that there is a positive correlation between gender equality and nonviolence/peace. ${ }^{265}$ Sponsel also notes the work of David Fabbro, who has provided a more comprehensive list of those attributes that are absent and those that are present in peaceful communities.

Peaceful communities, says Fabbro, do not have intergroup violence or feuding, internal or external warfare, a threat from an external enemy group or nation, social stratification, a fulltime political leader or centralized authority, or police or military organizations. $\frac{266}{\text { Peaceful }}$ societies, he argues, tend to be small and open communities with face-to-face, interpersonal interactions, possess an egalitarian social structure, maintain a generalized notion of reciprocity, reach decision making through group consensus, and encourage nonviolent values throughout the

\footnotetext{
${ }^{264}$ See Monkey See Monkey Do for a study of business organizations that concludes that individuals tend to follow the prevailing norms of the organization in which they work.

${ }^{265}$ Sponsel, supra note 114.
} 
community. 267 This list would seem to argue against a hierarchical community structure and, given the size and bureaucracy of multinational corporations, 268 the likelihood of the other attributes related to interpersonal interaction and equality seem remote. Indeed, Nicholas Carr notes that globalization works directly against these tendencies even though it pays lip service to a diluted dimension of cooperation in terms of teams. Carr states that

to be flexible is to lack attachments...but forming connections and communities, holding on to one's olive trees -just being able to decorate your own desk and call it your home away from home - is one of the most defining characteristics of human beings. Globalization, by creating a world in which we are constantly being asked to break such connections, reinvent ourselves, think in the short term and stay flexible, sets us all adrift and leaves everyone feeling like a temporary worker ... we don't bond with others; we "team" with them. We don't have friends; we have contacts. We're not members of enduring nurturing communities; we're nodes in ever-shifting, coldly utilitarian networks. 269

It is important to note, of course, that the anthropological studies of nonviolent studies are not done within the context of multinational business organizations. One of the salient characteristics of these groups, in fact, runs entirely counter to the thrust of globalization in that these groups are often remotely located so that external threats are rare. ${ }^{270}$ In contrast, globalization connects people so that they cannot be remotely aloof from the rest of the world. Nevertheless, the efficacy of face-to-face interaction in open communities has been demonstrated in school mediation situations in which

disputants are few in number, know each other well through daily interaction, and expect to have an ongoing relationship after the dispute is resolved. Close to 90 percent of those involved in school peer mediating, for example, report satisfaction with the agreement and are willing to honor their agreements over time. In contrast, peer

\footnotetext{
${ }^{266}$ David Fabbro, Peaceful Societies: An Introduction, 15 J. PEACE RES. 67 (1978).

${ }^{267} I d$. at 108.

${ }^{268}$ See, e.g. ROBERT JACKALl, MORAL MAZES THE WORLD OF CORPORATE MANAGERS (1988).

${ }^{269}$ FRIEDMAN, supra note 8, at 424-25 (citing Carr).

${ }^{270}$ Sponsel, supra note 114.
} 
mediation with large groups is often less effective.

The anthropologists are onto a conception of mediating institutions. Mediating institutions are relatively small organizations where moral identity and behavior is formed. ${ }^{272}$ The sizes of organizations are critical because "people can be themselves only in small comprehensible groups." $" 273$ Large business organizations, like any large organization, $\frac{74}{74}$ may contain economic efficiencies, but "most of the sociologists and psychologists insistently warn us of ... dangers to the integrity of the individual when he feels as nothing more than a small cog in a vast machine and when the human relationships of his daily working life become increasingly dehumanized.

A central difficulty of modernity is its emphasis on large organizations. As Michael Nagler writes that the shift from oikos networks to that of poleis in ancient times and further codified by the nation-state system "led in similar ways to less peace in their respective systems . . because they swept aside valuable modes of association that had evolved in their respective cultures while creating a framework for even larger polarizations. ${ }^{276}$ Yet, small-scale organizations do not necessarily have the perspective by which they can adopt policies for a common good, such as the environment. Homer-Dixon, for instance, argues that small groups in developing countries may already have wealth, power and status because of their extant social

\footnotetext{
${ }^{271}$ DAVID STEele, STEVEn Brion-MeISEIS, GARy Gunderson, EdWARd LeRoy LONG, JR., USE CoOPERATIVE CONFLICT RESOLUTION 59.

${ }^{272}$ See Timothy L. ForT, Ethics AND GOVERnANCE: BusinesS AS MEDIATING INSTITUTION (2001).

${ }^{273}$ SCHUMACHER, supra note 229 , at 80.

${ }^{274}$ See VACLAV HAVEL for a comparison of the attributes of socialist organizations and large corporations because of the dimunition of the importance of the individual in each. Fort \& Schipani, supra note 157, at 831 (citing Vaclav Havel, Disturbing the Peace: A Conversation with Karel hVizdala 14 (Paul Wilson trans., ALFRED A. KNOPF 1990) (1986)).

${ }^{275}$ SCHUMACHER, supra note 229, at 257.

${ }^{276}$ Michael N. Nagler, Ideas of World Order and the Map of Peace, in APPROACHES TO PEACE supra note 117, at 378 .
} 
position. ${ }^{277}$ As such, they frequently have narrow interests that can impede efforts to establish social institutions, laws, and other broader interests of society. $\stackrel{278}{ }$ In critiquing Robert Putnam, whose civic association reliance would challenge the above argument, Homer-Dixon writes that "social segmentation can tear apart the civic networks essential to building and maintaining social trust and good will; in turn, loss of trust and good will removes a critical restraint on the severity and harmfulness of the social competition that arises from greater environmental scarcity."

The central task of a governance system that fosters peace then is one that both allows for the development of community, which empowers individuals by providing them with a voice in the institutions that govern them together with transparency so that actions of any one group or multiples of groups can be evaluated and called to account. ${ }^{280}$ We therefore propose a corporate governance system that incorporates the attributes of peaceful societies as the criteria by which good governance can be evaluated and which blends existing models of successful corporate governance regimes into a workable model that can achieve both economic progress and social harmony. 281

\footnotetext{
${ }^{277}$ HOMER-DiXON, supra note 177, at 118.

${ }^{278} I d$.

${ }^{279} I d$. at 122.

${ }^{280}$ Schumacher explains the dilemma in this way: "we must learn to think in terms of an articulated structure that can cope with a multiplicity of small-scale units." SCHUMACHER, supra note 229, at 80.

${ }^{281}$ Metha, supra note 250 at 380-81.

Gandi ... saw the ideal world as a system in which individuals would voluntarily serve the family, the family would serve the state, the state the nation, and the nation the entire world: 'In this structure composed of innumerable villages there will be ever-widening, ever-ascending circles. Life will not be a pyramid with the apex sustained by the bottom. But it will be an oceanic circle whose center will be the individual always ready to perish for the village, the latter ready to perish for the circle of villages, till at last the whole becomes one life composed of individuals ... sharing the majesty of the oceanic circle of which they are integral units. Therefore, the outermost circumference will not wield power to crush the inner circle, but will give strength to all within an derive its own strength from it.
} 


\section{DAVIDSON INSTITUTE WORKING PAPER SERIES - Most Recent Papers}

The entire Working Paper Series may be downloaded free of charge at: www.wdi.bus.umich.edu

CURRENT AS OF 1/17/02

\begin{tabular}{|c|c|c|}
\hline Publication & Authors & Date \\
\hline No. 422: The Role of the Corporation in Fostering Sustainable Peace & Timothy Fort and Cindy Schipani & Nov. 2001 \\
\hline No. 421: Wage Arrears and the Distribution of Earnings in Russia & $\begin{array}{l}\text { Hartmut Lehmann and Jonathan } \\
\text { Wadsworth }\end{array}$ & Dec. 2001 \\
\hline $\begin{array}{l}\text { No. 420: Transferring Collective Knowledge: Collective and } \\
\text { Fragmented Teaching and Learning in the Chinese Auto Industry }\end{array}$ & $\begin{array}{l}\text { Jane Zhou, Jaideep Anand, and } \\
\text { Will Mitchell }\end{array}$ & Dec. 2001 \\
\hline $\begin{array}{l}\text { No. 419: Liberalization, Corporate Governance, and the Performance of } \\
\text { Newly Privatized Firms }\end{array}$ & $\begin{array}{l}\text { Narjess Boubakri, Jean-Claude } \\
\text { Cosset, and Omrane Guedhami }\end{array}$ & Dec. 2001 \\
\hline $\begin{array}{l}\text { No. 418: The European Data Privacy Directive and International } \\
\text { Relations }\end{array}$ & Steven R. Salbu & Dec. 2001 \\
\hline $\begin{array}{l}\text { No. 417: Capital Markets and Capital Allocation: Implications for } \\
\text { Economies in Transition }\end{array}$ & $\begin{array}{l}\text { Artyom Durnev, Randall Morck, } \\
\text { and Bernard Yeung }\end{array}$ & Dec. 2001 \\
\hline $\begin{array}{l}\text { No. } 416 \text { Forthcoming in: The Journal of Economic Perspectives, "Data } \\
\text { Watch. Research Data from Transition Economies," 16(2) Feb. } 2002 .\end{array}$ & $\begin{array}{l}\text { Randall K. Filer and Jan } \\
\text { Hanousek }\end{array}$ & Dec. 2001 \\
\hline $\begin{array}{l}\text { No. } 415 \text { Forthcoming in: The Journal of Economic Perspectives, } \\
\text { "Transition Economies: Performance and Challenges," 16(2) Feb. } 2002 .\end{array}$ & Jan Svejnar & Dec. 2001 \\
\hline $\begin{array}{l}\text { No. } 414 \text { Forthcoming in: The Journal of Economic Perspectives, "The } \\
\text { Great Divide and Beyond: Financial Architecture in Transition," 16(2) } \\
\text { Feb. 2002. }\end{array}$ & Erik Berglof and Patrick Bolton & Dec. 2001 \\
\hline $\begin{array}{l}\text { No. } 413 \text { Forthcoming in: The Journal of Economic Perspectives, "The } \\
\text { Political Economy of Transition," 16(2) Feb. } 2002 .\end{array}$ & Gérard Roland & Dec. 2001 \\
\hline $\begin{array}{l}\text { No. 412: The Response of Consumption in Russian Households to } \\
\text { Economic Shocks }\end{array}$ & Steven Stillman & Oct. 2001 \\
\hline No. 411: Mark-ups in Hungarian Corporate Sector & László Halpern and Gábor Körösi & Aug. 2001 \\
\hline No. 410: Economic Development, Legality, and the Transplant Effect & $\begin{array}{l}\text { Daniel Berkowitz, Katarina } \\
\text { Pistor, Jean-Francois Richard }\end{array}$ & Sept. 2001 \\
\hline No. 409: Development Strategy, Viability, and Economic Convergence & Justin Yifu Lin & Oct. 2001 \\
\hline No. 408: Labor Supply, Informal Economy and Russian Transition & Maxim Bouev & May 2001 \\
\hline No. 407: Corporate Governance in China: Then and Now & ani and Liu Junhai & Nov. 2001 \\
\hline No. 406: Entrepreneurship and Post-Socialist Growth & $\begin{array}{l}\text { Daniel Berkowitz and David N. } \\
\text { DeJong }\end{array}$ & Oct. 2001 \\
\hline $\begin{array}{l}\text { No. } 405 \text { Forthcoming in: European Economic Review, "Policy Reform } \\
\text { and Growth in Post-Soviet Russia." }\end{array}$ & $\begin{array}{l}\text { Daniel Berkowitz and David N. } \\
\text { DeJong }\end{array}$ & Oct. 2001 \\
\hline $\begin{array}{l}\text { No. 404: Social Policies and Structures: Institutional Frictions and Traps } \\
\text { in the Czech Republic after } 1989\end{array}$ & Jiří Večerník & Nov. 2001 \\
\hline $\begin{array}{l}\text { No. 403: Investment, Efficiency, and Credit Rationing: Evidence from } \\
\text { Hungarian Panel Data }\end{array}$ & Mathilde Maurel & Nov. 2001 \\
\hline $\begin{array}{l}\text { No. 402: Subduing High Inflation in Romania. How to Better Monetary } \\
\text { and Exchange Rate Mechanisms? }\end{array}$ & $\begin{array}{l}\text { Daniel Daianu and Radu } \\
\text { Vranceanu }\end{array}$ & Aug. 2001 \\
\hline $\begin{array}{l}\text { No. 401: The Gender Wage Gap in Bulgaria: A Semiparametric } \\
\text { Estimation of Discrimination }\end{array}$ & Dean Jolliffe & July 2001 \\
\hline $\begin{array}{l}\text { No. 400: Do External Auditors Perform a Corporate Governance Role in } \\
\text { Emerging Markets? Evidence from East Asia }\end{array}$ & Joseph P. H. Fan and T.J. Wong & Oct. 2001 \\
\hline $\begin{array}{l}\text { No. 399: Financial Conditions and Investment during the Transition: } \\
\text { Evidence from Czech Firms }\end{array}$ & Lubomír Lízal and Jan Svejnar & Oct. 2001 \\
\hline $\begin{array}{l}\text { No. 398: Accessible Pareto-Improvements: Using Market Information to } \\
\text { Reform Inefficiencies }\end{array}$ & Michael Mandler & May 2001 \\
\hline No. 397: The Making of an Integrated National Grain Market in China & Wubiao Zhou & Oct. 2001 \\
\hline No. 396: Corruption and Resource Allocation: Evidence from China & Wei Li & June 2001 \\
\hline
\end{tabular}

